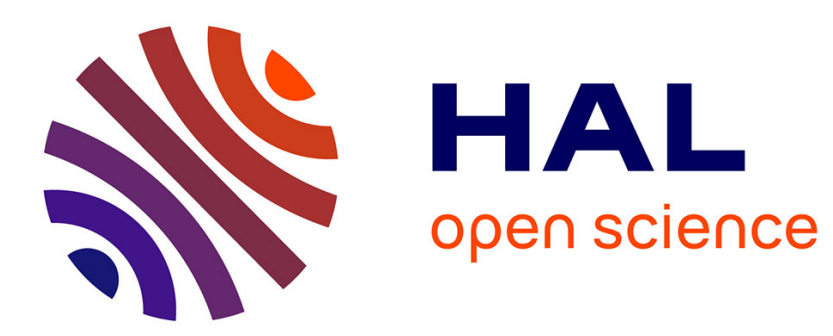

\title{
Electrochemical Methodologies for the Detection of Pathogens
}

Mandana Amiri, Abolfazl Bezaatpour, Hamed Jafari, Rabah Boukherroub, Sabine Szunerits

\section{- To cite this version:}

Mandana Amiri, Abolfazl Bezaatpour, Hamed Jafari, Rabah Boukherroub, Sabine Szunerits. Electrochemical Methodologies for the Detection of Pathogens. ACS Sensors, 2018, 3 (6), pp.1069-1086. 10.1021/acssensors.8b00239 . hal-02189343

\section{HAL Id: hal-02189343 \\ https://hal.science/hal-02189343}

Submitted on 19 Jul 2019

HAL is a multi-disciplinary open access archive for the deposit and dissemination of scientific research documents, whether they are published or not. The documents may come from teaching and research institutions in France or abroad, or from public or private research centers.
L'archive ouverte pluridisciplinaire HAL, est destinée au dépôt et à la diffusion de documents scientifiques de niveau recherche, publiés ou non, émanant des établissements d'enseignement et de recherche français ou étrangers, des laboratoires publics ou privés. 


\section{TOC image}

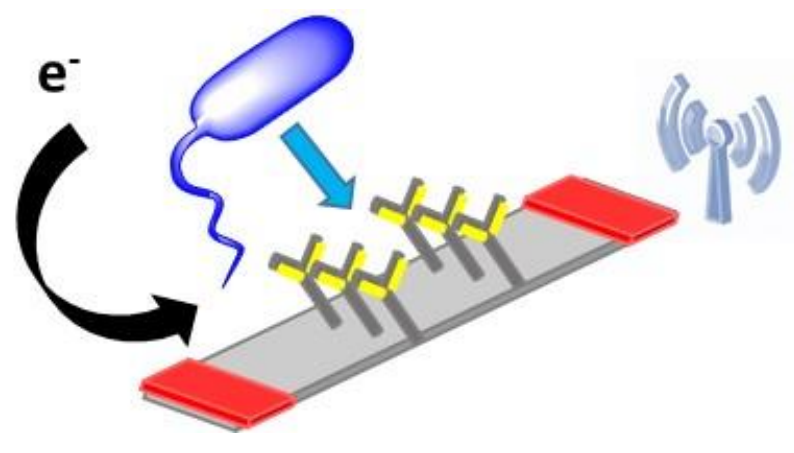




\title{
Electrochemical methodologies for the detection of pathogens
}

\author{
Mandana Amiri, ${ }^{1 *}$ Abolfazl Bezaatpour, ${ }^{1}$ Hamed Jafari, ${ }^{1}$ Rabah Boukherroub, ${ }^{2}$ Sabine \\ Szunerits $^{2 *}$ \\ ${ }^{1}$ Department of Chemistry, University of Mohaghegh Ardabili, Ardabil, Iran \\ ${ }^{2}$ Univ. Lille, CNRS, Centrale Lille, ISEN, Univ. Valenciennes, UMR 8520-IEMN, F-59000 Lille, \\ France
}

\begin{abstract}
Bacterial infections remain of the principal causes of morbidity and mortality worldwide. The number of death due to infections is declining every year by only $1 \%$ with a forecast of 13 million deaths in 2050. Among the 1400 recognized human pathogens, the majority of infectious diseases is caused by just a few, about 20 pathogens only. While the development of vaccinations and novel anti-bacterial drugs and treatments are at the forefront of research, and strongly financially supported by policy makers, another manner to limit and control infectious outbreaks is targeting the development and implementation of early warning systems, which indicate qualitatively and quantitatively the presence of a pathogen. As toxin contaminated nutrition and drinks are a potential threat to human health and have consequently a significant socio-economic impact worldwide, the detection of pathogenic bacteria remains not only a big scientific challenge but also a practical problem of enormous significance. Numerous analytical methods, including conventional culturing and staining techniques as well as molecular methods based on polymerase chain reaction amplification and immunological assays have emerged over the years and are used to identify and quantify pathogenic agents. While being highly sensitive in most cases, these approaches are highly time, labor and cost consuming, requiring trained personnel to perform the frequently complex assays. A great challenge in this field is therefore to develop rapid, sensitive, specific, and if possible miniaturized devices to validate the presence of pathogens in cost and time efficient manners.

Electrochemical sensors are well accepted powerful tools for the detection of disease-related biomarkers, environmental and organic hazards. They have also found widespread interest in the
\end{abstract}

\footnotetext{
${ }^{*}$ To whom corresponds should be send to: Mandana Amiri (mandanaamiri@yahoo.com), sabine Szunerits (sabine.szunerits@univ-lill.fr)
} 
last years for the detection of waterborne and foodborne pathogens due to their label free character and high sensitivity. This review is focused on the current electrochemical-based microorganism recognition approaches and putting them into context of other sensing devices for pathogens such as culturing the microorganism on agar plate and the polymer chain reaction (PCR) method, able to identifying the DNA of the microorganism. Recent breakthroughs will be highlighted, including the utilization of microfluidic devices and immunomagnetic separation for multiple pathogen analysis in a single device. We will conclude with some perspectives and outlooks to understand better shortcomings. Indeed, there is currently no adequate solution that allows the selective and sensitive binding to a specific microorganism, that is fast in detection and screening, cheap to implement, and able to be conceptualized for a wide range of biologically relevant targets.

Keywords: pathogen; electrochemistry; sensing; toxins; bacteria

\section{Vocabulary section:}

1. Analytical Electrochemistry: is the application of electrochemical processes to measure the quantity of a species of interest.

2. Aptamers: Nucleic acids that bind to targets with affinities in the micro to picoMolar range, analogous with binding constants of antibodies/antigen interactions

3. Biosensor: analytical device involving a biological sensing part with wide range of applications, including food safety, environmental monitoring, and health monitoring.

4. Biofilm: biofilms comprise any group of microorganisms in which cells stick to each other and often also to a surface.

5. Bacterophage: A virus that infects and replicates within Bacteria 
The detection of pathogenic microorganisms remains a big scientific challenge and a practical problem of enormous significance. Per year, an estimated 250 million people are affected by pathogenic bacteria, of which about $8 \%$ are fatal. ${ }^{1}$ An early state detection of some of these infections would have avoided lengthy treatments and many of the death counts. The gold standard for bacteria detection remains microorganism culturing on agar plates (Figure 1A). While bacteria are too small to be visualized with the naked eyes, upon culture on an agar plate with nutrition medium, the bacteria cells can divide rapidly and form a visible patch, appearing as white, cream, or yellow in color, and fairly circular in shape. This diagnostic scheme takes a minimum of 24 hours, ignoring viable but non-culturable cells. Bacteria plating is often followed by standard biochemical identification using a set of tests such as catalase test, citrate test, gram staining, methylene red staining etc. Gram staining using crystal violet/iodine is probably the most commonly used technique as it allows to differentiate Gram positive from Gram negative bacteria. Gram-negative bacteria get decolorized when exposed to alcohol. Gram-negative bacteria can thus subsequently be stained with safranin and appear red in color. This is in contrast to Gram-positive bacteria with a thick peptidoglycan layer with low lipid content. Decolorizing with alcohol causes cell wall dehydration and shrinkage and prevents the release of the stain from the cells and leaving a blue/purple coloring (Figure 1B). Another widely applied test is based on the use of methyl red (MR). The principle the MR test is based on the knowledge that some bacteria have the ability to metabolize glucose to pyruvic acid, metabolized to lactic acid, acetic acid or formic acid as end product. The acid produced decreases the $\mathrm{pH}$ indicated by a change in the color of MR from yellow to red. For example, Enterobacter aerogenes or Klebsiella pneumonia give a negative MR test remaining yellow, while Escherichia coli ATCC 25922 results in a positive MR test and red color (Figure 1B).

To avoid the limitations of culture-dependent techniques, a variety of molecular approaches have been established. ${ }^{2}$ The use of molecular techniques allowed the characterization of microbial communities without the requirement of culturing the microorganism. These approaches are based on extraction and purification of bacterial DNA and RNA. Simple fluorescence based approaches $^{3}$ using labeled oligonucleotide probes binding to microbial DNA are largely used and are based on is low cytometry (FC), which monitors bacterial abundance and cell viability in suspension using fluorescent dyes (Figure 1C). ${ }^{4}$ 
Next to these approaches, polymer chain reaction (PCR) method introduced in 1980s, is able to identifying the DNA of microorganisms (Figure 1D). ${ }^{5-6}$ Since 2005 , the development of nextgeneration sequencing, together with decreasing costs for sequencers and reagents have made microbial genomics more accessible. However, while a large number of DNA microarrays are commercially available, not even a handful are adapted for microbial analysis, where low and medium density arrays serve as ideal platforms. Among some of the chips commercially available are Helicobacter pylori arrays from MWG Biotech (www.mwg-biotech.com), $M$. tuberculosis, C. albicans and Plasmodium falciparum from OPERON (www.operon.com), E. coli arrays from Pan Vera (www.panvera.com), E. coli and P. aeruginosa arrays from Affymetrix (www.affymetrix.com), E. coli and M. tuberculosis arrays from Sigma-Genosys ( low-density microarray designed to detect various staphylococcus species. Specifically, it uses PCR with degenerate primers to amplify the femA gene, a highly conserved staphylococcal peptidoglycan gene. These DNA products are then analyzed on the microarray bearing capture probes specific to five staphococcal species that are most closely linked to hospitalization-related infections-S. aureus, S. haemolyticus, S. epidermidis, S. saprophyticus and S. hominis. A microarray platform to distinguish between different Pseudomonas species was developed by researchers at Michigan State University. ${ }^{8}$ Unlike the previous example, PCR-amplified genomic fragments were immobilized on the array interface rather than small oligonucleotides and probed the arrays with labeled fragments of genomic DNA from various bacterial isolates.

The advantages of these approaches are the quick profiling, detection of different microorganisms simultaneously, and the possibility to analyze a large number of samples simultaneously. The drawbacks are that all these approaches remain rather time consuming and laborious. In the case of the FISH method, for specific detection the sequence information for probe design is required. The high cost and time-consuming data analysis of high-throughput sequencing techniques as well as microarray technology is often a limiting factor for their application. 


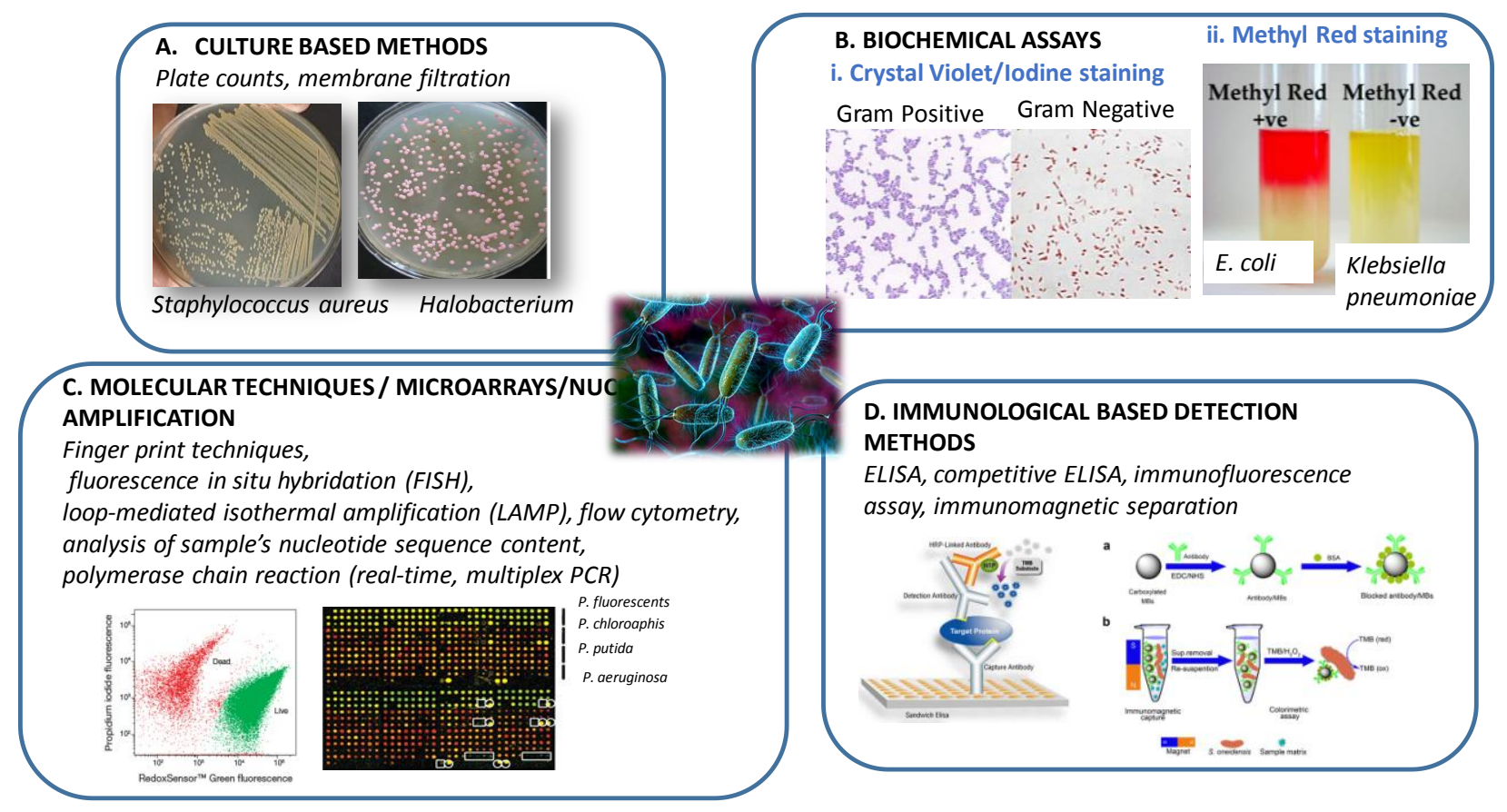

Figure 1: Current approaches for bacteria detection and quantification: (A) Culturedependent approach such as plate counting; (B) Differentiation between bacteria strains using biochemical assays such as crystal violet/iodine staining or the methylene red assay; (C) Molecular approaches: (left): Flow cytometry image of killed and healthy S. aureus cells when stained with propidium iodide and RedoxSensor Green (Reprinted with permission from Ref. ${ }^{9}$; Copyright 2008/Springer Nature,); (right) PCR based methods: image of microarray used for the diagnosis of infections using PCR-amplified genomic fragments from various Pseudomonas spp. (Reprint with permission from Ref. ${ }^{8}$; Copyright 2001, American Society for Microbiology); (D) Immunological based methods: (left) sandwich ELISA, (right) Colorimetric immunomagnetic assay.

Apart from the specific sequences that reside in the genome of bacteria, antibodies can be used for specific targeting of bacteria. Immunological-based methods, using polyclonal or monoclonal antibodies, have become common methods for bacteria detection (Figure 1D). Although immunological detection methods less sensitive and specific than nucleic-acid based schemes, they are faster and the sensitivity can be enhanced through heterogeneous assays such as enzyme-linked immunosorbent assays (ELISA), competitive ELISA, ELISA coupled to immunomagnetic separation or immunofluorescence assays. Sandwich ELISA is mainly used, where a capture antibody is coated to the solid phase in an ELISA plate. After addition of the bacteria solution, detection antibodies are added. Further exposure to enzyme-linked antibodies 
will result in a color change in the presence of a substrate (e.g. 3, 3', 5, 5'-tetramethylbenzidine $(\mathrm{TMB}))$ in the case of a positive event which can be measured with a spectrophotometer where the intensity is proportional to the level of antibodies present in the samples. In the case of immunofluorescence assays, antibodies are labeled with fluorescence reporter molecules and can be used directly to detect bacteria in clinical samples. It is to be noted that the use of polyclonal antibodies will lack specificity. Immunomagnetic separation involves magnetic nanoparticles coated with antibodies. Adding these beads to bacteria solutions results in bacteria capture, which can be magnetically isolated. ${ }^{10}$ Analysis of the captured bacteria is then possible using peroxidase-amplified colorimetric readout.

While in plate based ELISA tests antigen binding to bacteria and its detection stages are separated in time, the use of biosensors have the intrinsic advantage that bacteria binding to antibody directly triggers a signal that can be detected by a proper detector (depending on the design of the detection system (Figure 2). The term "biosensor" describes an analytical device involving a biological sensing part with wide range of applications, including food safety, environmental monitoring, and health monitoring. The advantages of biosensors for bacteria detection compared to other molecular analysis techniques are their cost effectiveness and fast response generally within the minute range. When compared to the ELISA format, the use of flow cells and small surface of immersed probe makes ligand-bacteria interaction similar to interaction occurring in a liquid phase. This contrasts with ELISA, where a strictly two-phase system, liquid analyte and solid phase bound antibodies, is used which needs more time to equilibrate between both phases and results in analysis times of hours rather than minutes as is the case of biosensors. While most biosensors cannot currently discriminate between live and dead microorganism, they can give a first fast quantitative and qualitative estimation of the pathogens, which is in most cases enough to decide on the follow up steps.

The use of electrochemical sensors, which started in 1962 with the construction of a glucometer using glucose oxidase-based sensors, has become widely accepted concept. The possibility of miniaturization, multiplexing together with the ability of construction of flexible, disposable and cheap electrochemical sensing devices has made electrochemical sensors very attractive for many applications where sensitivity, simplicity of operation, fast response time, and low cost are 
essential. The improvements reported in detection limits as well in specificity of electrochemical biosensors in the last decade is mainly due to the achievements realized in materials science and subsequent availability of a wide range of nanomaterials and composite materials with good electrical conductivity and/or catalytic activity. As most electrochemical and electrical sensors are label-free sensing devices, their potential for pathogen detection is large and have been widely considered as inexpensive and powerful alternatives over molecular pathogen detection approaches. The review focuses on the advancements made in the last 5 years in this field.

\section{First step in the design of an electrochemical pathogen sensor: Surface modification}

One important aspect in any biosensor design is linked to the way the pathogen-specific ligand is attached to the surface. A variety of transducer surfaces are available onto which different bioreceptors such as antibodies, polysaccharides, aptamers, bacteriophages, etc can be easily immobilized (Figure 2).

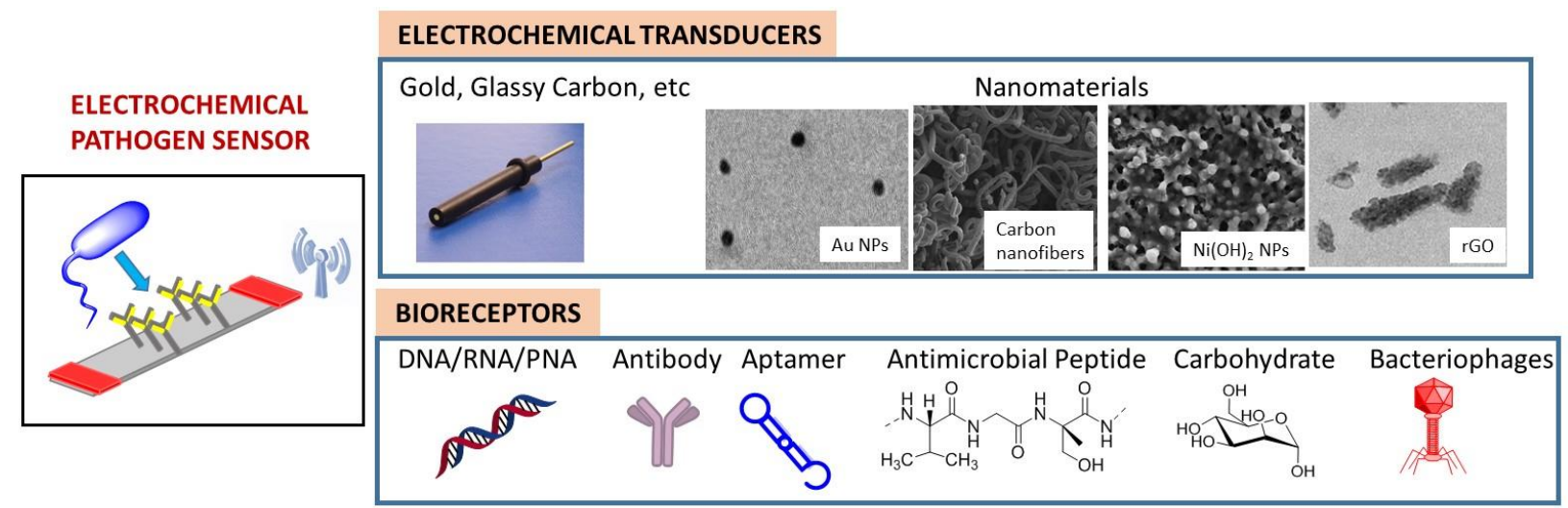

SURFACE MODIFICATION STRATEGIES

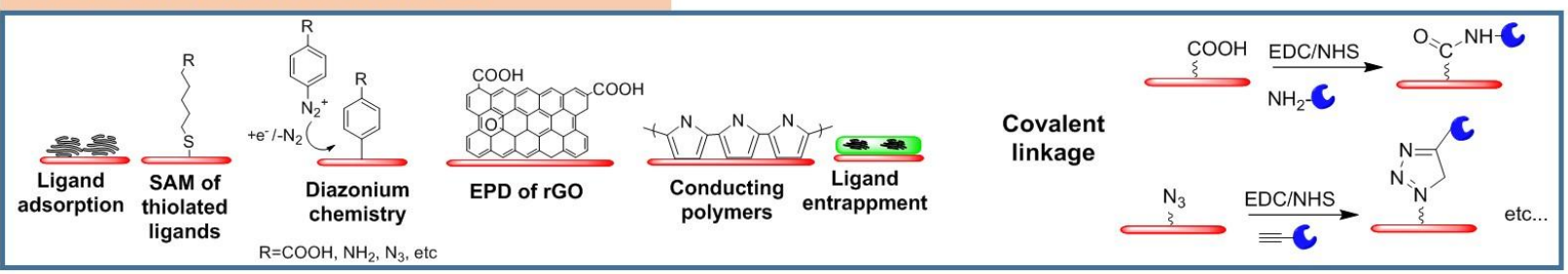

ELECTROCHEMICAL DETECTION SCHEMES
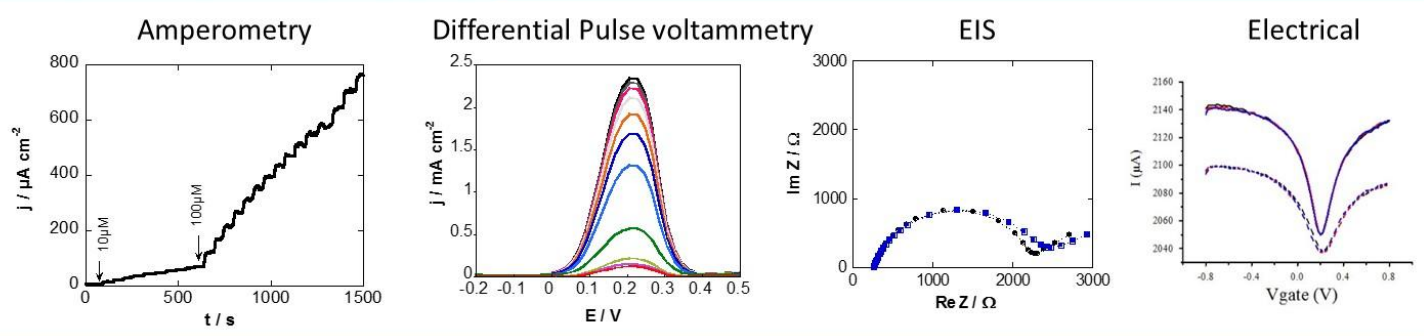
Figure 2: Biosensors for pathogen detection and quantification in food, water and human serum samples: (A) Bioreceptors used; (B) Most common electrode materials used; (C) Surface modification strategies; (D) Different electrochemical detection approaches reported.

Bacteria tend to attach reversibly to solid surfaces during the initial contact; eventually the microorganism starts secreting exopolysaccharides which results in their irreversible adhesion to the surface, often in the form of biofilms. ${ }^{11}$ While the timescale in pathogen sensing is usually not enough for biofilms to form, non-specific adsorption has to be minimized to fully take advantage of a biosensing device. Surface chemistry plays thus a significant part not only in linking the biological recognition element onto the sensing surface but also to block the electrode against non-specific interactions. The existing immobilization strategies include bioreceptor adsorption, entrapment and encapsulating in polymers, and covalent linking approaches. Whatever the chosen strategy, it has to be ensured that both the accessibility of the bioreceptor to the target molecule and its recognition capability have to be preserved. The main classes of biological recognition elements used in pathogenic sensors are next to nucleic acids, antibodies, aptamers, baceriophages. ${ }^{12}$

\section{Adsorption}

\section{Non-specific adsorption}

Adsorption is an easy manner to modify an electrode surface with a pathogen recognition element in a completely random way. Proteins may however partially denature and lose their function. Optimal conditions need to be determined for each biorecognition element, with an optimal surface coverage often being achieved for most proteins on uncharged surfaces at neutral $\mathrm{pH}$ and physiological ionic strength using concentrations of 5-20 $\mu \mathrm{g} / \mathrm{mL}$. Yang et al. established an impedimetric immunosensor by adsorption of anti-E. coli antibodies onto integrated microelectrode arrays for the detection of E. coli O157:H7 with a detection limit being however rather high, $10^{6} \mathrm{cfu} \mathrm{mL}^{-1} \cdot 13$

The surface modification with protein $\mathrm{G}$ and $\mathrm{A}$, surface receptors produced by numerous bacteria strains, can promote binding of bioreceptors. As each protein A and $\mathrm{G}$ can indeed bind 4 and 2 molecules of IgG. 
A similar approach is that using the strong binding of the glycoprotein avidin to biotinfunctionalized bioreceptors due to the strong dissociation constant of $1.3 \times 10^{-15} \mathrm{M}$ of the avidin/biotin complex. E. coli as low as $10-100 \mathrm{cfu} \mathrm{mL}^{-1}$ in concentration could be detected on avidin modified electrodes using biotinylated anti-E. coli. as recognition ligand. ${ }^{14}$ The high isoelectric point of avidin ( $\mathrm{IP}=10)$ together with its carbohydrate content made the use of streptavidin, a similar glycan-free protein with an IP of 5-6, of higher interest. However, high levels of non-specific bacteria adhesion were reported on streptavidin chips. ${ }^{15}$

\section{Self-assembled monolayers (SAMs)}

SAMs are chemisorbed layers formed by spontaneous organization of thiolated molecules on metallic interfaces, with the most widely used SAMs being derived from $n$-alkanehtiols on gold. ${ }^{16}$ Functional SAMs are frequently the base for immobilization of pathogenic recognition elements using covalent approaches. Geng et al. used for example mercaptoacetic acid to from SAM for immobilization of anti-E. coli antibodies on gold electrodes with a reported detection limit of $10^{3} \mathrm{cfu} \mathrm{mL}^{-1} .{ }^{17}$ Electrochemical immunosensing platforms composed of thiolated chitosan (CHI-SH) modified electrodes offered also interfaces rich in $-\mathrm{SH}$ functional groups. ${ }^{18}$

\section{Covalent attachment}

Numerous strategies exist for the covalent coupling of recognition ligands to electrochemical interfaces and lessons from protein arrays were useful in establishing optimal conditions. A commonly used strategy consists in crosslinking carboxylic acid groups on the electrode surface and/or on the biorecognition element with amine groups on ligand or surface, respectively, exploiting amide bond formation using EDC/NHS chemistry. Furthermore, this coupling strategy is also successfully applied to three-dimensional supports, such as agarose, aldehyde-agarose and carboxymethylated dextran modified electrodes. ${ }^{19}$

The use of carboxylic acid modified pyrene ligands is particularly useful for the modification of carbon based materials such as reduced graphene oxide as well as carbon nanotubes through $\pi-\pi$ stacking interaction, offering the possibility for covalent attachment via EDC/NHS chemistry. ${ }^{20-22}$ Covalent integration of functional groups using diazonium chemistry has also been lately proposed by some authors. ${ }^{23-24}$ 


\section{Imprinting}

A rather different approach is the entrapment of bacterial recognition ligands or the bacteria itself into polymer and sol-gel matrixes. The dissolution of the imprinted structures results in something which got known as molecular imprinted polymers (MIPs). MIPs are thus nothing else than artificial receptor ligands. As they are resistant to degradation and inactivation, some

efforts have been put onto the development of MIPs for electrochemical pathogen detection. ${ }^{25-30}$

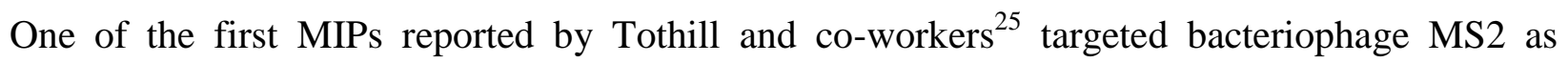
template for the detection of water born viruses, using a surface plasmon based read out. Golabi et al. demonstrated recently the potential of cell imprinted polymers as recognition elements for selective bacteria detection. ${ }^{27}$ 3-Aminophenylboronic acid (3-APBA) was used for the fabrication of a cell-imprinted polymer (Figure 3A). Boronic acid functions are able to specifically and reversibly interact with cis-diol molecules, ${ }^{31}$ which facilitates easy release of captured bacterial cells and subsequent regeneration of the CIP. Using S. epidermidis as a model target and EIS as a detection method, detection in the range of $10^{3}-10^{7} \mathrm{cfu} \mathrm{mL}^{-1}$ was achieved. Roy et al. reported an impedimetric sensor based on cell-mediated films for E. coli using of Ag$\mathrm{ZnO}$ nanoparticle and graphene oxide (Ag- $\mathrm{ZnO} @ \mathrm{GO}) .{ }^{30}$ Using scanning wave voltammetry and ferrocyanide redox species, the sensor detected $E$. coli as low as $10 \mathrm{cfu} \mathrm{mL}^{-1}$ and allowed capturing $98 \%$ of the bacterial cells, which could be in addition ablated photothermally. An electrochemiluminescence (ECL) biosensor based on a polydopamine imprinted polymer and nitrogen-doped graphene quantum dots (N-GQDs) for E. coli O157:H7 detection was proposed by Chen et al. (Figure 3B) $)^{22 d}$. Removal of E. coli O157:H7 from the polydopamine film, selective recognition is achieved upon labeling with E. coli O157:H7 polyclonal antibody (pAb) conjugated to N-GQDs, which generates intensive ECL in the presence of $\mathrm{K}_{2} \mathrm{~S}_{2} \mathrm{O}_{8}$. Under optimal conditions a limit of detection of $8 \mathrm{cfu} \mathrm{mL}^{-1}$ was attained. Jiang et al. opted for the synthesis of magnetic molecular imprinted polymer on glassy carbon electrodes capable of selectively absorbing Gram-negative bacterial signaling molecules. Using differential pulse voltammetry (DPV), quorum signaling molecules could be detected down to $0.8 \mathrm{nM}$. $^{\mathbf{2 8}}$ 


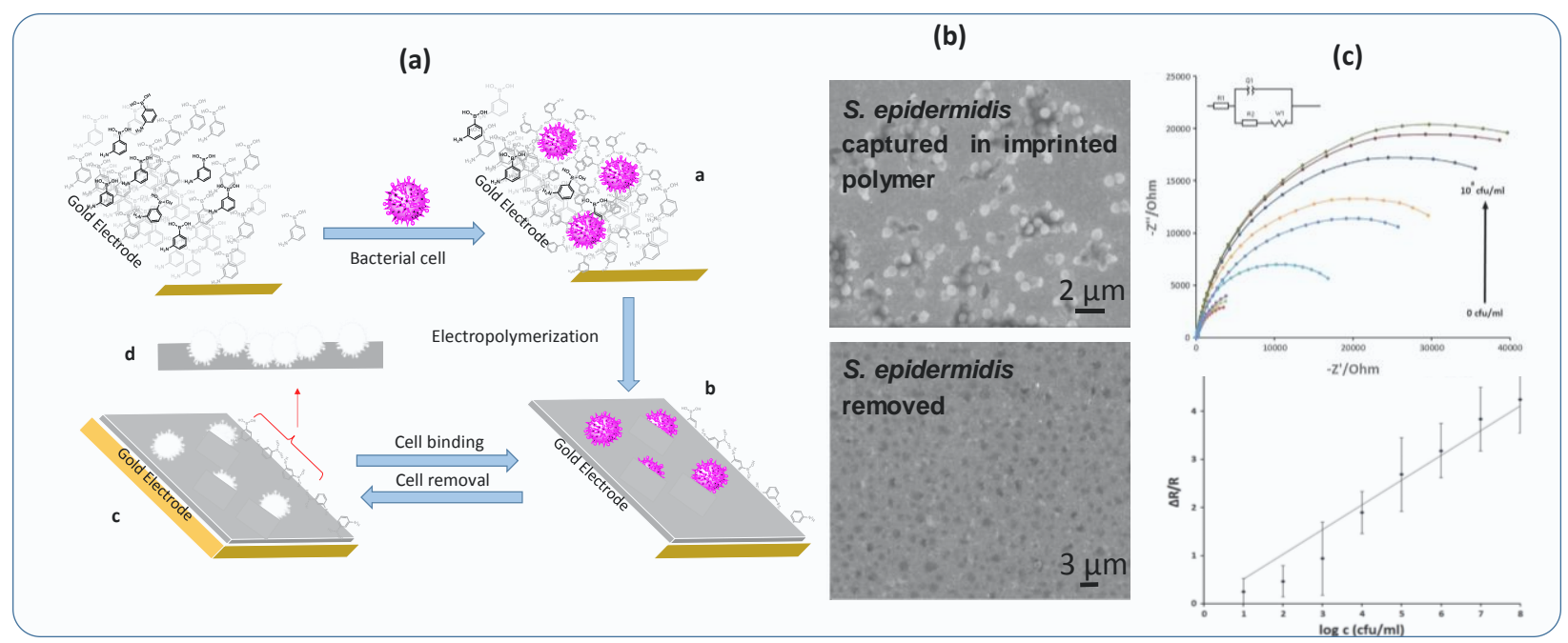

(B)

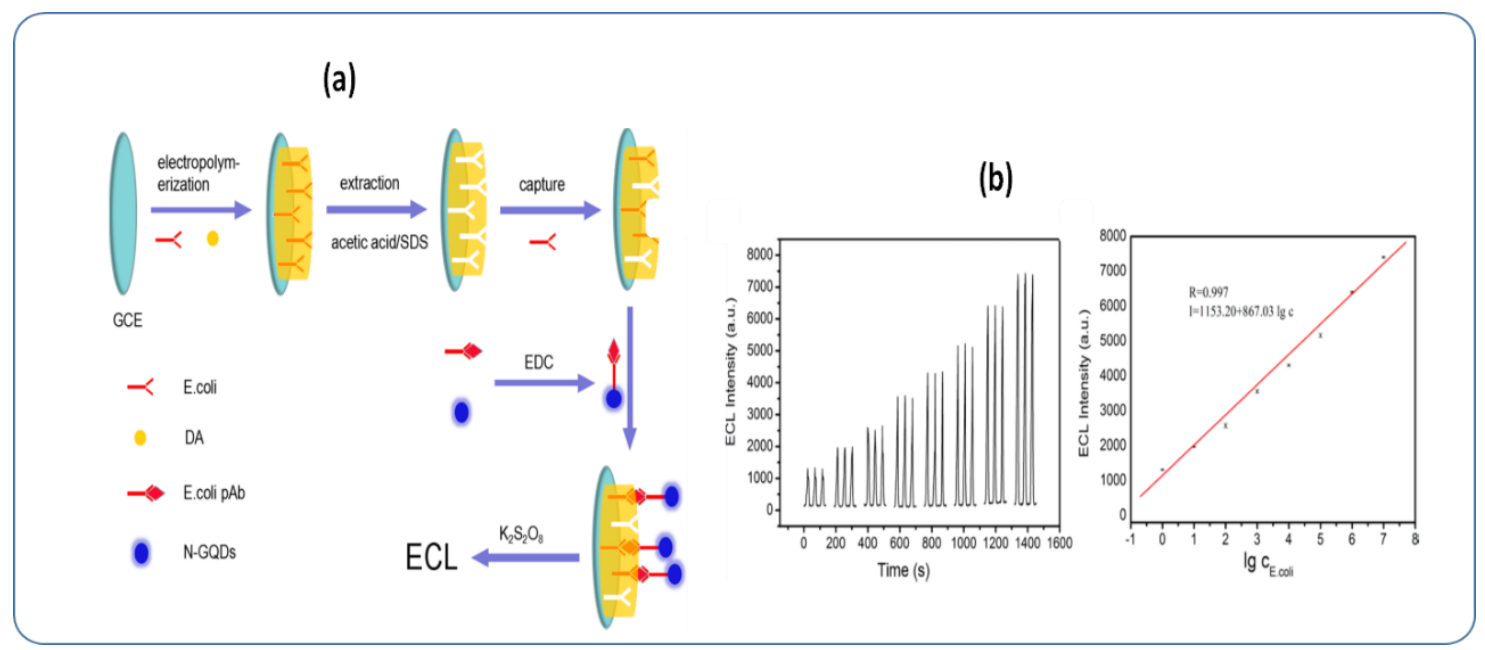

Figure 3: EIS based whole cell imprinting sensor for $S$. epidermis detection. (A) (a) Imprinting strategy: Boronic acid groups attach to the surface of bacteria, electropolymerisation; Bacterial cells are removed, complementary cavities remain; (b) SEM images of S. epidermidis captured in imprinted polymer before and after removal; (c) EIS results upon incubation with different concentrations of S. epidermidis together with calibration curve. Experimental details: 5 $\mathrm{mM} \mathrm{K}_{3}\left[\mathrm{Fe}(\mathrm{CN})_{6}\right] / \mathrm{K}_{4}\left[\mathrm{Fe}(\mathrm{CN})_{6}\right](1: 1)$ in PBS; frequency range $0.1-10,000 \mathrm{~Hz}$, bias potential of $0.0 \mathrm{mV}$ vs. OCP. (Reprint with permission Ref. ${ }^{27}$ Copyright 2017, Elsevier); (B) (a) Illustration of fabrication of biosensor with detection process, (b) ECL trace for different E. coli concentrations together with calibration curve (Reprint with permission from Ref. ${ }^{26}$; Copyright 2017/American Chemical Society) 


\section{DNA based sensors}

DNA sensors have revolutionized modern analysis due to their stability and low-cost, making them a versatile building block for the fabrication of new devices in nanotechnology and biosensor technology. Most literature has focused on genosensors due to their high specificity. Electrochemical DNA sensors are also effective tools for the rapid detection of pathogens with high sensitivity and selectivity. The most crucial step in the preparation is the surface immobilization of the DNA strands. Subsequent interaction with a specific fragment gene from the pathogen causes changes in the DNA structure or the assembly and the electrochemical properties of the interface which can be assessed using impedimetric as well as voltammetric read outs (Figure 4A). Electrochemical detection of DNA are divided into direct and indirect approaches (Figure 4B). The direct methods use the electroactivity of DNA itself or the changes in the interfacial properties of the DNA-modified electrode such as capacitance, conductivity or impedance. The indirect methods rely on the use of electrochemical active DNA intercalators ${ }^{32}$ (e.g. methylene blue) ${ }^{33-34}$ or labels ${ }^{35}$ such as enzymes (e.g. horseradish peroxidase), ${ }^{36}$ redox mediators (e.g. $\mathrm{Ru}\left(\mathrm{NH}_{3}\right)_{6}{ }^{2+}$ ), ${ }^{37}$ particles ${ }^{34}$ to amplify the read out. ${ }^{38-40}$ The literature is rather rich (Table 1) and some examples will be highlighted in the following section.

(A)

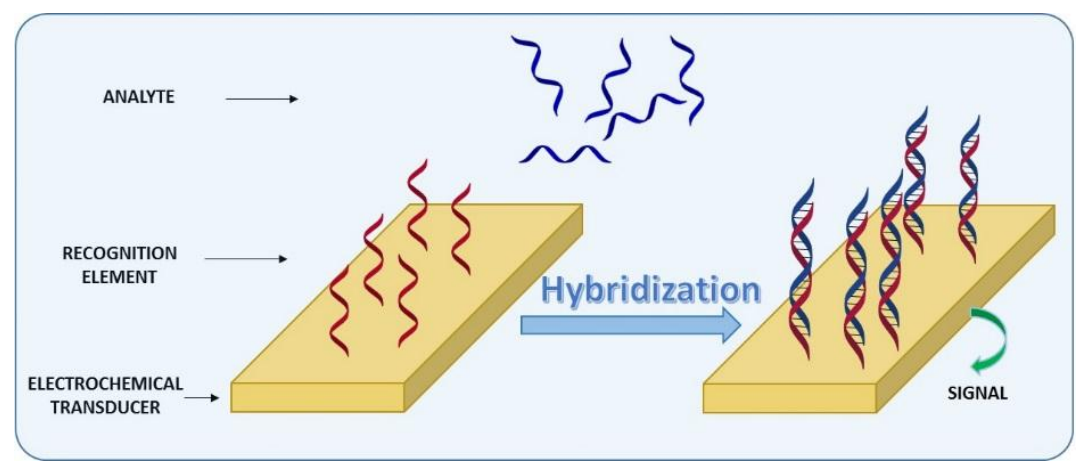

(B) 

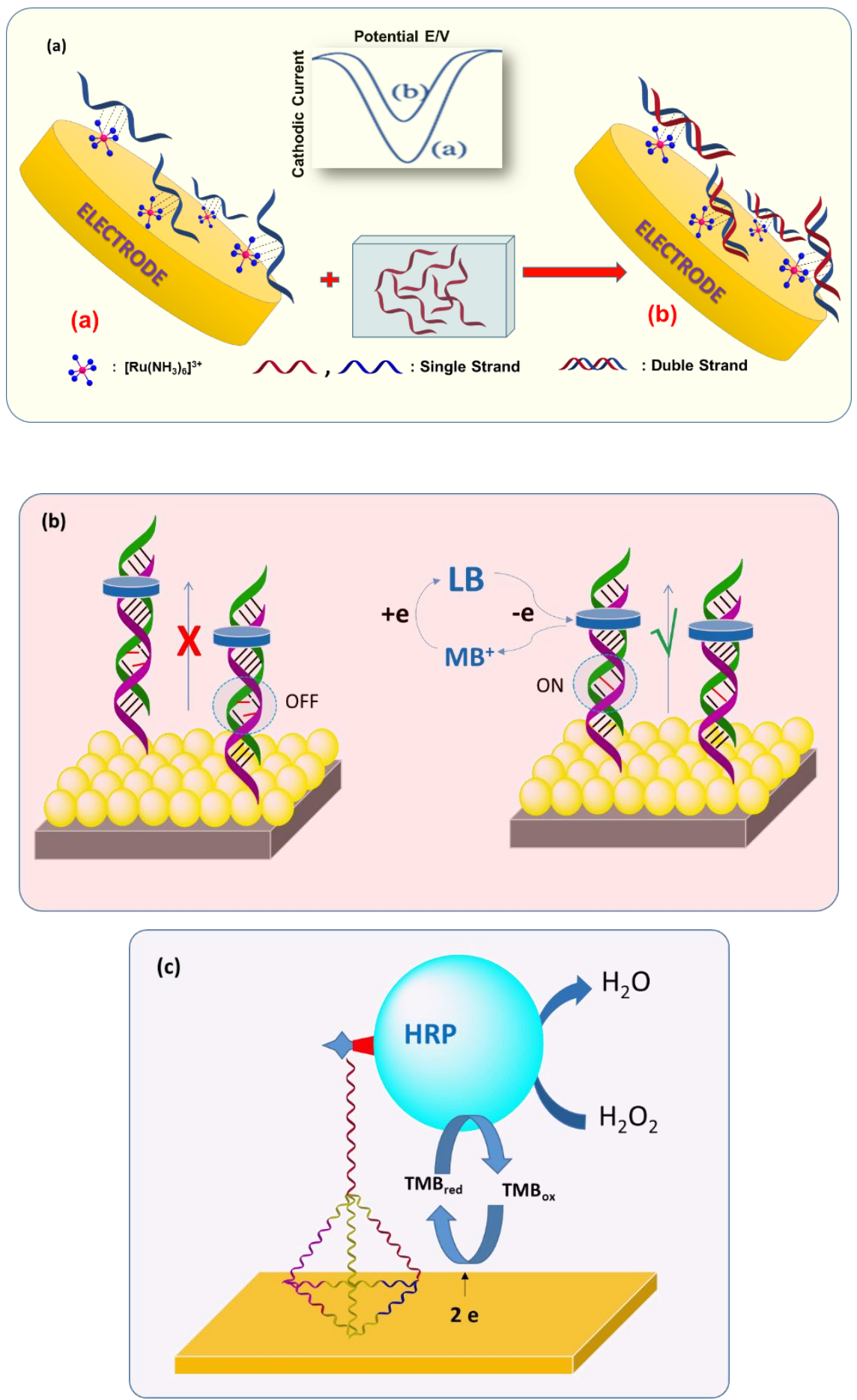

Figure 4. Schematic of a DNA biosensor for pathogen detection: (A) Direct method; (B) Indirect method based on (a) $\mathrm{Ru}\left(\mathrm{NH}_{3}\right)_{6}{ }^{2+}$ as redox mediator, (b) methylene blue, (c) enzyme (HRP). 
Electrochemical detection of $E$. coli and $S$. aureus using a LAMP amplicon was demonstrated by Ahmed et al. ${ }^{37}$ Abdalhai et al. reported an electrochemical genosensor for the detection of pathogenic E. coli $\mathrm{O} 157: \mathrm{H7}$ in fresh beef samples. ${ }^{38}$ The genosensor was fabricated by immobilization of DNA molecules on a gold surface, able to hybridize with a specific fragment gene from E. coli. Further interaction with CdS NPs modified with sDNA resulted in a sandwich structure, which upon immersion into $\mathrm{HNO}_{3}$ resulted in the release of $\mathrm{Cd}^{2+}$. The amount of $\mathrm{Cd}^{2+}$ detected is proportional to the amount of pathogenic E. coli $\mathrm{O} 157: \mathrm{H} 7 .^{38}$

A sensor consisting of multiwalled carbon nanotubes (MWCNTs) covered with polypyrrole, polyamido amine dendrimers and ferrocenyl groups as a redox marker was proposed by Miodek et al. for electrochemical sensing of rpoB gene of M. tuberculosis in real PCR samples with a detection limit of $0.3 \mathrm{fM}$ (Figure 5A) ${ }^{41}$

Amperometric DNA sensors were found also to be valuable tools for the detection of viruses. ${ }^{36} \mathrm{~A}$ DNA probe was immobilized onto a gold electrode through self-assembly using thiolated nucleotide sequences and a longer nucleotide sequence of complementary DNA. The captured target sequence was hybridized using biotinylated ssDNA oligonucleotide. Addition of avidinlabeled horseradish peroxidase and 3,3',5,5'-tetramethylbenzidine as substrate molecule allowed for the specific recognize of target DNA fragments of influenza viruses with a detection limit of $100 \mathrm{fM}$ for target nucleotide sequences. ${ }^{36}$

Vi. parahaemolyticus, a bacterium being the leading cause of seafood-associated gastroenteritis and one of the most important food-borne pathogens, could be sensed electrochemically using screen printed carbon electrodes modified with polylactide-stabilized gold nanoparticles and MB (methylene blue). ${ }^{34}$ Detection was assessed through the reduction of peak current of methylene blue against $\log \mathrm{C}_{\mathrm{DNA}}$. This approach proved to be able to determine residues of the pathogen in extracted DNA samples, without the need of cleanup or purification steps. 
(a)

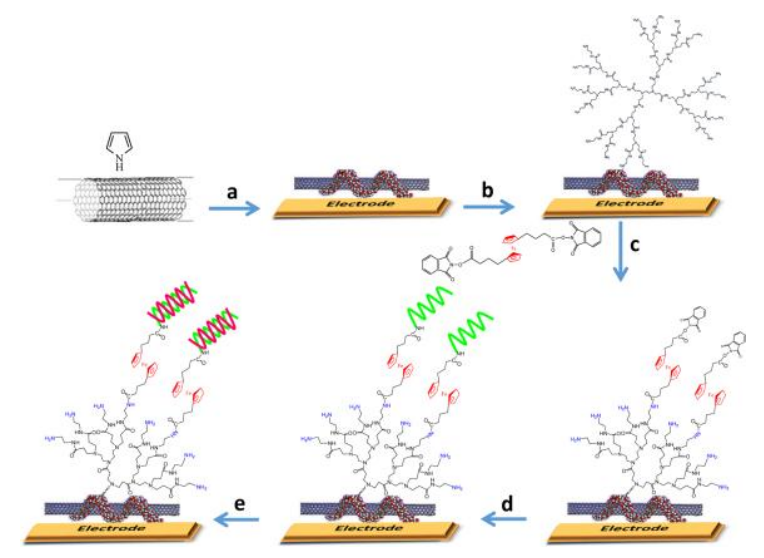

(b)

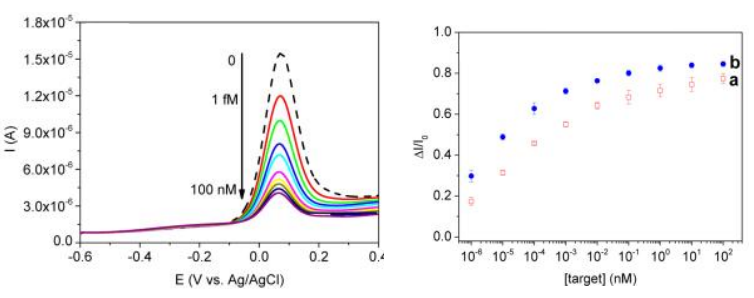

(B)

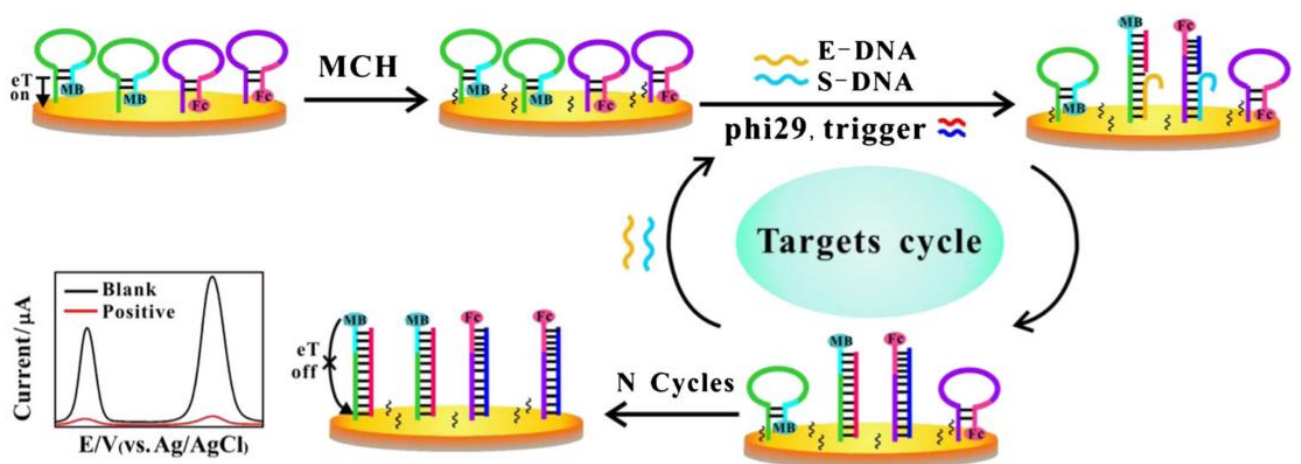

Figure 5: (A) (a) Biosensor preparation using MWCNTs coated with polypyrrole, PAMAM and ferrocene for bacterial DNA detection; (b) SWVs after hybridization of complementary target DNA ( $1 \mathrm{fM}$ to $100 \mathrm{nM}$ ), amplitude $=20 \mathrm{mV}$, frequency= $50 \mathrm{~Hz}$, conditioning time $=180 \mathrm{~s}$ together with changes of peak current with concentration of (a) DNA and (b) DNA $\mathrm{DArgets}_{\mathrm{L}}$ on the MWCNTs-PPy-PAMAM-Fc biosensor (Reprint with permission from Ref. ${ }^{41}$, Copyright 2015 American Chemical Society); (B) Multiplexed electrochemical sensor for the sensitive detection of E. coli O157:H7 and Salmonella typhimurium (Reprint with permission from Ref. ${ }^{42}$ Copyright 2017, Springer Nature).

A rapid voltammetric sensor using polymerase-assisted target recycling amplification for the simultaneous determination of E. coli O157:H7 and S. typhimurium by detecting the rfbE gene of E. coli $0157: H 7$ and gyrB gene of S. typhimurium was developed by Guo et al. ${ }^{42}$ The sensor 
was constructed via self-assembly of the respective hair-pin probes, labeled with methylene blue and ferrocene, onto gold electrode (Figure 5C). After hybridization with the target DNA, the primers hybridize with the open-chain hair-pin probes and initiate extension reactions in the presence of polymerase and deoxyribonucleoside triphosphates. This results in the release of the redox labels and the target dissociating from the hair-pin probes. The released target binds to other hair-pin probes to activate new cycles, resulting in enhanced suppression of current, measured at $-0.27 \mathrm{~V}$ and $+0.36 \mathrm{~V}$ for detection of E. coli DNA and S. typhimurium DNA, respectively.

Table 1: DNA based pathogenic sensors.

\begin{tabular}{|c|c|c|c|c|c|}
\hline Analyte & Method & Sensitivity & LOD & Linear range & Ref. \\
\hline E. coli & Potentiometry & $0.19 \mathrm{nM} / \mathrm{mV}$ & $1 \mathrm{nM}$ & - & \\
\hline E. coli O157:H7 & EIS & $21.485 \Omega / \log \mathrm{c}$ & $0.1 \mathrm{fM}$ & $10^{-14}-10^{-6} \mathrm{M}$ & 44 \\
\hline E. coli & $\mathrm{CA}$ & & $10^{3}{\mathrm{cfu} \mathrm{mL}^{-1}}^{-1}$ & & 45 \\
\hline E. coli O157:H7 & DPV & $\begin{array}{l}2.3501 \mu \mathrm{A} / \ln (\mathrm{g} \\
\left.\mathrm{mL}^{-1}\right)\end{array}$ & $1 \mathrm{ng} \mathrm{mL}^{-1}$ & $10^{-9}-10^{-6} \mathrm{~g} \mathrm{~mL}^{-1}$ & 46 \\
\hline E. coli & DPV & - & $6.3 \mathrm{pmol}$ & $21-400 \mathrm{pmol}$ & 47 \\
\hline$E$; coli UTI & & & & & 18 \\
\hline $\begin{array}{l}\text { E. coli O157:H7 } \\
\text { S. typhimurium }\end{array}$ & DPV & - & $\begin{array}{l}0.32 \mathrm{fM} \\
0.67 \mathrm{fM}\end{array}$ & $\begin{array}{l}0.5 \mathrm{fM}-5 \mathrm{pM} \\
1 \mathrm{fM}-5 \mathrm{pM}\end{array}$ & 42 \\
\hline E. coli $16 \mathrm{~S}$ rRNA & $\mathrm{CA}$ & - & $250 \mathrm{cfu} \mathrm{mL}^{-1}$ & - & 48 \\
\hline E. coli & & & $\begin{array}{l}3.6 \times 10^{3} \mathrm{cfu} \\
\mathrm{mL}^{-1}\end{array}$ & - & 49 \\
\hline S. aureus & DPV & $0.469 \mu \mathrm{A} / \mathrm{M}$ & $0.244 \mathrm{fM}$ & - & 38 \\
\hline S. typhimurium & DPV & $0.269 \mu \mathrm{A} / \operatorname{lg~c}$ & $28 \mathrm{cfu} \mathrm{mL}^{-1}$ & $72-10^{6} \mathrm{cfu} \mathrm{mL}^{-1}$ & 50 \\
\hline Salmonella & SWV & - & $0.4 \mu \mathrm{M}$ & - & 35 \\
\hline Salmonella & DPV & $2.66 \mu \mathrm{A} / \log \mathrm{c}$ & $10 \mathrm{cfu} \mathrm{mL}^{-1}$ & $10-10^{5} \mathrm{cfu} \mathrm{mL}^{-1}$ & 51 \\
\hline Aphanomyces invadans & ASV/DPV & - & $1 \mathrm{fM}$ & - & 52 \\
\hline Aeromonas hydrophila & SWV & - & $100 \mathrm{fM}$ & - & 33 \\
\hline Vibrio cholerae & DPV & $35.20 \mathrm{nA} / \mathrm{ng} \mathrm{cm}^{-2}$ & $31.5{\mathrm{ng} \mu \mathrm{L}^{-1}}^{-1}$ & $100-500 \mathrm{ng} \mu \mathrm{L}^{-1}$ & 53 \\
\hline Streptococcus Pneumoniae & SWV & $0.437 \mu \mathrm{A} / \log \mathrm{c}$ & $0.093 \mathrm{cfu} \mathrm{mL}^{-1}$ & $5-100 \mathrm{cfu} \mathrm{mL}^{-1}$ & 54 \\
\hline Pneumococcal protein A & SWV & $0.271 \mu \mathrm{A} / \mathrm{ng} \mathrm{mL}^{-1}$ & $0.218 \mathrm{ng} \mathrm{mL}^{-1}$ & $0-8 \mathrm{ng} \mathrm{mL}^{-1}$ & 54 \\
\hline Vibrio parahaemolyticus & DPV & $0.425 \mu \mathrm{A} \mu \mathrm{M}^{-1}$ & $2.16 \mathrm{pM}$ & $20 \mathrm{pM}-20 \mathrm{nM}$ & 25 \\
\hline Piscirickettsia salmonis & & $0.86 \mu \mathrm{A} \mathrm{M}^{-1} \mathrm{~mm}^{-2}$ & $0.5 \mathrm{nM}$ & $0.5 \mathrm{nM}-1 \mathrm{mM}$ & 40 \\
\hline $\begin{array}{l}\text { Mycobacterium } \\
\text { tuberculosis }\end{array}$ & CA & - & $1 \mathrm{fM}$ & $1-100 \mathrm{aM}$ & 39 \\
\hline hepatitis B virus (HBV) & ASV & - & $85 \mathrm{pM}$ & $0-500 \mathrm{pM}$ & 55 \\
\hline $\begin{array}{l}\text { avian influenza A (H7N9) } \\
\text { virus }\end{array}$ & CA & - & $100 \mathrm{fM}$ & $1 \mathrm{pM}-100 \mathrm{nM}$ & 36 \\
\hline
\end{tabular}

EIS: Electrochemical impedance spectroscopy; ASV: anodic stripping voltammetry; CA: chronoamperometry; SWV: square wave voltammetry; DPV: differential pulse voltammetry. 


\section{Antibody-based sensors}

Antibody-modified sensors allow for fast and sensitive analysis of a large range of pathogens

toxins (Table 2). ${ }^{56}$ Emphasis was on the detection of foodborne microorganisms over the years, ${ }^{57}$ and additional examples dealing with fungal pathogens, mycotoxins, viruses and marine toxins are provided. Polyclonal antibodies are widely used, but have often not the mandatory specificity for sensing. Monoclonal antibodies are produced using hybridoma technology using murine hosts., while recombinant antibodies ones are formed using phage display technology. These antibodies are not entirely exploited, while having important advantages such as enhanced selectivity and specificity as well as the possibility to incorporate tags for isolation, immobilization and characterization. When selecting an antibody for pathogen detection, certain characteristics are sought after. It should detect very low cell numbers as this represents a frequent issue in pathogen sensing, and differentiate specific strain. ${ }^{58}$

Gehring et al. demonstrated already more than 10 years ago the interest of biotinylated caprine derived antibodies for $E$. coli $\mathrm{O} 157: \mathrm{H} 7$ detection on streptavidin coated microarray slides and fluorescence-labeled secondary antibodies for captured cell readout. ${ }^{59}$ This concept was later applied to electrodes: the coupling of specific antibodies to electrode transducers converting the binding into an electrical signal has proven more attractive than the optical read out, as no secondary antibody to reveal the binding event was necessary. ${ }^{60}$ An amperometric sensor for the detection of S. typhimurim cells, captured with magnetic bead-conjugated antibodies, after addition of alkaline-phosphatase labeled goat anti-Salmonella antibodies using paraaminophenol as substrate was proposed with a sensitivity of $8 \times 10^{3}$ cells $\mathrm{mL}^{-1}{ }^{60}$ An electrochemical magneto-immunosensor for the specific detection and quantification of bacteria has also been reported by others. ${ }^{61}$ In this case, a competitive immunoassay involving S. aureus ProtA antigen labelled with horseradish peroxidase is used (Figure 6A). The electrochemical conversion of hydrogen peroxide to water using tetrathiafulvalene (TTF) as electron transfer mediator resulted in a detection limit for $S$. aureus of $3.9 \times 10^{-9} \mathrm{cfu} \mathrm{mL}^{-1}$. Indeed, the literature on the use of enzyme-label amplification strategies to achieve lower detection limits for pathogens dates back to Ruan et al., who reported a detection limit of $6 \times 10^{3} \mathrm{cfu} \mathrm{mL}^{-1}$ using HRP-labeled secondary antibodies that produce a precipitate of insoluble products on the electrode surface and thus an insulation layer blocking electron transfer. ${ }^{62}$ 
E. coli $\mathrm{O} 157: \mathrm{H} 7$ cells isolated by commercial immune-magnetic beads modified with antibodies and further labeled with polyaniline nanoparticles modified with monoclonal anti-E. coli O157:H7 antibodies by direct physical adsorption allowed magnetically-driven positioning of the samples on screen-printed carbon electrodes. ${ }^{63}$ The presence of E. coli O157 cells inhibits the current flow and used for sensing. This method was used for a variety of target organisms, with the possibility to be a fully transportable system for routine monitoring or bacterial pathogens. ${ }^{63}$ Chowdhury has used equally the conducting nature of polyaniline films covalently modified with E. coli O157:H7 antibodies for the impedimetric sensing of E. coli:O157:H7. ${ }^{64}$

(A)
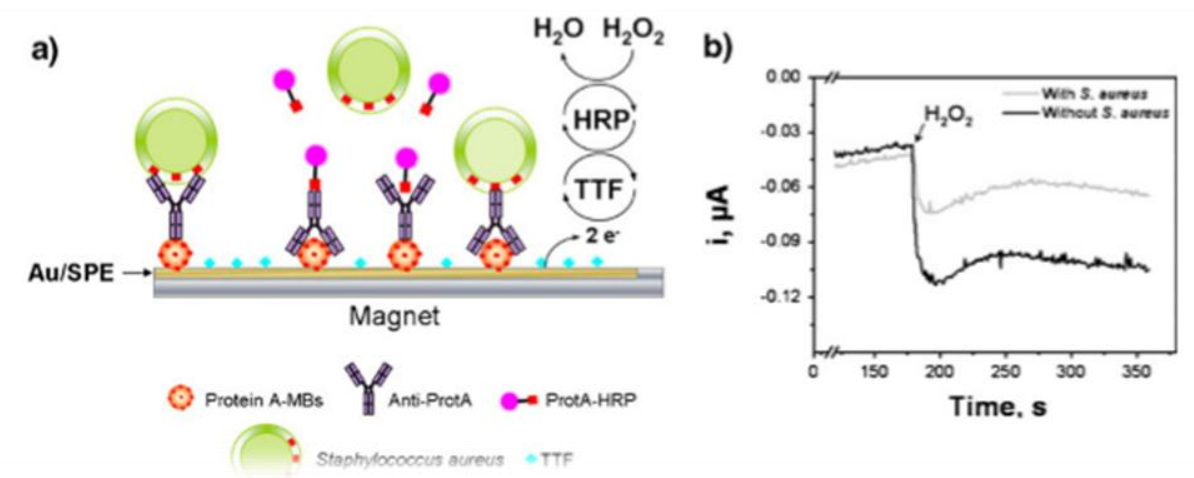

(B)

(a)

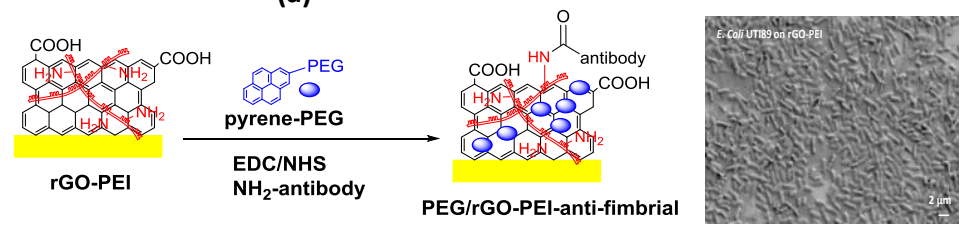

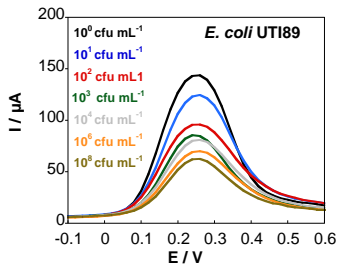

(c)

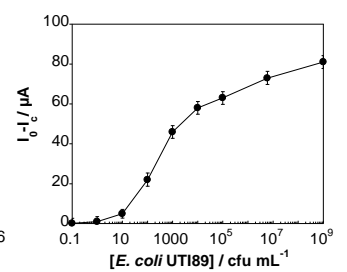

Figure 6: (A) (a) Electro-magneto immunosensor of $S$. aureus, (b) mediated reduction of $\mathrm{H}_{2} \mathrm{O}_{2}$ with TTF in the presence and absence of S. aureus $\left(10^{5} \mathrm{cfu} \mathrm{mL}^{-1}\right)$ (Reprint with permission of Ref. $^{61}$, Copyright 2012, Springer Nature; (B) (a) Construction steps of immunosensor for E. coli UTI89, (b) SEM image of rGO/PEI coated Au electrode after immersion into a solution of $E$.

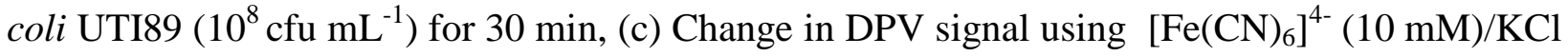


(0.1 M), 30 min incubation in E. coli UTI89 solutions using the electrode and the corresponding calibration curve (Adapted with permission from Ref. ${ }^{21}$; Copyright 2018, Elsevier).

While such approaches can be easily extended to microarrays, consisting of a panel of pathogenspecific antibodies patterned onto separate positions on microarray slides, and as such represent an excellent candidate for high-throughput analysis of pathogens in miniaturized format, ${ }^{65}$ most research in this field is directed on the search for new electrode materials and amplification strategies to enhance the performance of the sensors for bacterial detection. Wang et al. proposed in 2010 a 3D immune-sensor consisting of antibody functionalized 3D foam Ni electrode for the detection of sulfate-reducing bacteria between $2.1 \times 10^{1}-2.1 \times 10^{7} \mathrm{cfu} \mathrm{\textrm {mL } ^ { - 1 }}{ }^{66}$ Antibody functionalized single walled carbon nanotubes (SWCNT) modified electrodes were successfully applied for the selective detection of $S$. aureus using differential pulse voltammetry. A selectivity assay using E. coli, Bacillus subtilis, and S. epidermidis showed that the sensor was specific to $S$. aureus. $^{67}$

Fei and co-workers constructed recently an electrochemical immune magnetic sensor for $S$. pullorum and $S$. gallinarum using antibody modified $\mathrm{Fe}_{3} \mathrm{O}_{4} / \mathrm{SiO}_{2} / \mathrm{AuNPs}$ nanocomposites (AuMNPs). ${ }^{68}$ After capture and separation of the pathogens by AuMNPs by an external magnetic field, the formed AuMNPs-Salmonella complexes were exposed to HRP-labeled anti-S. pullorum and S. gallinarum (HRP-Ab2). Modification of SPC electrodes with gold nanoparticles through electrodeposition and using thionine as redox allowed the detection of S. pullorum and $S$. gallinarum with a detection limit of $89 \mathrm{cfu} \cdot \mathrm{mL}^{-1}$. In another work by the same group, reduced graphene oxide covered with gold nanoparticles (rGO/AuNPs) was proposed as electrochemical label for S. pullorum. ${ }^{68}$ some of us have reported recently the interest of electrodes modified with $\mathrm{rGO}$ /polyethyleneimine (PEI) thin film via electrophoretic deposition for the sensitive sensing of uropathogenic E. coli (Figure 6B). ${ }^{21}$ While rGO displays high surface area and good electrochemical properties, the presence of $-\mathrm{NH}_{2}$ groups offers a number of opportunities for surface functionalization, such as modificaiton with anti-fimbrial E. coli antibodies. To minimize non-specific adsorption, the sensor was further modified with poly(ethyleneglycol) (pyrenePEG) moieties. The immunosensor displayed a linear concentration range of $1 \times 10^{1}-1 \times 10^{4} \mathrm{cfu}$ 
$\mathrm{mL}^{-1}\left(\mathrm{R}^{2}=0.995\right)$ with a LoD of $10 \mathrm{cfu} \mathrm{mL}^{-1}$. The sensor worked also well in urine, and was able to differentiate E. coli UTI89 and UTI89 $\triangle$ fim.

Table 2: Antibody based pathogen sensors.

\begin{tabular}{|c|c|c|c|c|c|}
\hline Pathogen & $\begin{array}{l}\text { Detection } \\
\text { Method }\end{array}$ & Sensitivity & $\begin{array}{l}\text { LOD } \\
\text { cfu } \mathrm{mL}^{-1}\end{array}$ & $\begin{array}{l}\text { Linear dynamic } \\
\text { range/ } \mathrm{cfu} \mathrm{mL}^{-1}\end{array}$ & Ref. \\
\hline E. coli & EIS & & 10 & $10^{0}-10^{3}$ & \\
\hline E. coli & EIS & $951.428 \Omega / \log \mathrm{c}$ & - & $10^{3}-10^{8}$ & 70 \\
\hline E. coli O157:H7 & EIS & $429 \mathrm{~W} / \log \mathrm{c}$ & $10^{6}$ & $4.36 \times 10^{5}-3.2 \times 10^{8}$ & 13 \\
\hline E. coli O157:H7 & EIS & - & - & $10^{2}-10^{7}$ & 64 \\
\hline E. coli O157:H7 & LSV & - & 200 & $10^{3}-10^{8}$ & 71 \\
\hline E. coli O157:H7 & ECL & 867.03 a.u $/ \log c$ & 8 & $10^{1}-10^{7}$ & 26 \\
\hline E. coli O157:H7 & DPV & - & 10 & $10^{1}-10^{6}$ & 72 \\
\hline E. coli O157:H7 & EIS & $342.99 \Omega / \log \mathrm{c}$ & 1 & $10^{0}-10^{6}$ & 73 \\
\hline E. coli O157:H7 & DPV & $0.34 \mathrm{nA} / \mathrm{c}$ & 3 & $3 \times 10^{0}-3 \times 10^{2}$ & 74 \\
\hline E. coli O157:H7 & $\mathrm{CV}$ & - & 70 & $10^{1}-10^{5}$ & 75 \\
\hline E. coli O157:H7 & EIS & $2127 \mathrm{~W} / \log \mathrm{c}$ & 100 & $3 \times 10^{2}-3 \times 10^{8}$ & 76 \\
\hline E. coli O157:H7 & $\mathrm{CV}$ & $23.41 \mu \mathrm{A} / \log \mathrm{c}$ & 15 & $3.2 \times 10^{1}-3.2 \times 10^{6}$ & 77 \\
\hline $\begin{array}{l}\text { E. coli O157:H7 } \\
\text { Bacillus cereus }\end{array}$ & $\mathrm{CV}$ & - & $\begin{array}{l}6 \\
40 \\
\end{array}$ & - & 63 \\
\hline $\begin{array}{l}\text { E. coli O157:H7 } \\
\text { S. aureus }\end{array}$ & EIS & - & 100 & $10^{2}-10^{7}$ & 78 \\
\hline S. aureus & $\mathrm{DPV}, \mathrm{CV}$ & $1.7061 \mu \mathrm{A} / \log \mathrm{c}$ & 13 & $10^{1}-10^{7}$ & 67 \\
\hline S. aureus & amperometry & - & 1 & $10^{0}-10^{7}$ & 61 \\
\hline S. aureus & EIS & $15000 \mathrm{~W} / \log \mathrm{c}$ & 10 & $10^{1}-10^{7}$ & 79 \\
\hline $\begin{array}{l}\text { Salmonella } \\
\text { gallinarum }\end{array}$ & $\mathrm{CV}$ & $0.3418 \mu \mathrm{A} / \log \mathrm{c}$ & 32 & $10^{2}-10^{6}$ & 68 \\
\hline $\begin{array}{l}\text { Salmonella } \\
\text { pullorum }\end{array}$ & DPV & $0.3248 \mu \mathrm{A} / \log \mathrm{c}$ & 89 & $10^{2}-10^{6}$ & 68 \\
\hline Salmonella & $\mathrm{CA}$ & - & 13 & $10-10^{6}$ & 80 \\
\hline $\begin{array}{l}\text { Listeria } \\
\text { monocytogenes }\end{array}$ & CA & $548.0 \mathrm{nA} / \log \mathrm{c}$ & - & $10^{2}-10^{6}$ & 81 \\
\hline Listeria cells & EIS & $7932.6 \Omega / \log \mathrm{c}$ & 160 & $1.6 \times 10^{2}-1.6 \times 10^{5}$ & 82 \\
\hline $\begin{array}{l}\text { Streptococcus } \\
\text { pyogenes }\end{array}$ & $\begin{array}{l}\text { EIS } \\
\text { (Cumulative) } \\
\text { EIS (Single- } \\
\text { Shot) }\end{array}$ & $\begin{array}{l}- \\
-\end{array}$ & $\begin{array}{l} \\
-\end{array}$ & $\begin{array}{l}10^{4}-10^{7} \\
10^{4}-10^{6}\end{array}$ & 83 \\
\hline $\begin{array}{l}\text { Sulfate reducing } \\
\text { bacteria }\end{array}$ & EIS & $14.98 \mathrm{~W} / \log \mathrm{c}$ & 18 & $1.8 \times 10^{1}-1.8 \times 10^{7}$ & 84 \\
\hline $\begin{array}{l}\text { Hepatitis C core } \\
\text { antibody }\end{array}$ & $\mathrm{CV}$ & - & $12.3 \mathrm{pM}$ & $30 \mathrm{pM}-3 \mathrm{nM}$ & 85 \\
\hline $\begin{array}{l}\text { Japanese } \\
\text { encephalitis virus. }\end{array}$ & EIS & - & $10 \mathrm{ng} / \mathrm{mL}$ & $10-500 \mathrm{ng} / \mathrm{mL}$ & 86 \\
\hline
\end{tabular}

\section{Aptamer based sensors}

Aptamers have initiate lately large interest as recognition elements in biosensors replacing other commonly used bioreceptors, mainly antibodies. ${ }^{87}$ Aptamers are nucleic acids that bind to 
targets with affinities in the micro to picoMolar range, analogous with binding constants of antibodies/antigen interactions. Aptamers offer several advantages making them important emerging ligands for electrochemical pathogen sensing. ${ }^{87,} 88$ Their production does not necessitate an immune response in animals, as they are produced chemically by automated nucleic acid synthesis and by an in vitro selection process called SELEX (Systematic Evolution of Ligands by Exponential enrichment). ${ }^{89-90}$ Aptamers can be chemically modified which permits surface immobilization. Upon target binding, conformation changes occur which helps their detection using electrochemical techniques, where changes in current or potential correlate to analyte-aptamer interactions occurring at the surface. A variety of labels (horseradish peroxidase, glucose oxidase, alkaline phosphatase, ferrocene, nanoparticles, etc) can in addition be linked to aptamers, which in the case of electrochemical aptasensors can result in a single-on or signal-off format. ${ }^{87}$ Widely used for sensing of pesticides, ${ }^{87}$ one of the first examples for detection of bacteria is the aptamer-based carbon nanotube field effect transistor for E. coli $\mathrm{DH} 5 \mathrm{a},{ }^{91}$ or the nanoaptasensor by Cella for the detection of anthrax. ${ }^{92}$ Binding leads to a change in conductance of the functionalized electrodes. Labib and co-workers established an impedimetric aptamermediated sensor to detect living S. typhimurium (Table 3). The 6-hydroxyhexyl disulfide modified aptamer STYP-3 with a solution $\mathrm{K}_{\mathrm{D}}=25 \mathrm{mM}$ for $S$. typhimurium was linked over the thiol groups to gold and showed electron transfer blocking using $\mathrm{Fe}(\mathrm{CN})_{6}{ }^{3-/ 4-}$ as probe. The $\mathrm{R}_{\mathrm{CT}}$ increases linearly with increasing the concentration of $S$. typhimurium in the range of $10^{3}-10^{5} \mathrm{cfu}$ $\mathrm{mL}^{-1}$ with a LOD of $600 \mathrm{cfu} \mathrm{mL}^{-1}$ (Figure 7A). ${ }^{93}$

The first potentiometric electrochemical aptasensor for $S$. aureus is that by Zelada-Guillén and coworkers. $^{94,22}$ Single-walled carbon nanotubes were investigated as electrical conducting materials and anti-S. aureus SA43 aptamer was used as a recognition element to sense the conformation changes of the aptamer during interaction with $S$. aureus with LOD of $8 \times 10^{2}$ cfu $\mathrm{mL}^{-1}$ using covalently linkage strategies and $10^{7} \mathrm{cfu} \mathrm{mL}^{-1}$ when using a pyrene linking. ${ }^{22}$ Two years after, Hernandez et al. ${ }^{20}$ proposed a potentiometric aptasensor based on rGO as transducer layers modified with $S$. aureus S1A20 binding aptamer using covalent linkage between the $-\mathrm{NH}_{2}$ groups of the aptamer and the carboxylic groups of the rGO sheet and non-covalent binding via $\pi-\pi$ stacking interactions. Both sensors exhibited detection limits of $1 \mathrm{cfu} \mathrm{mL}{ }^{-1}$, with the covalent linked aptasensor being more easily regenerative. Abbaspour et al. recently designed a dualaptamer based sandwich using magnetic beads modified with S. aureus SA17 aptamer, which 
upon interaction with $S$. aureus, were further labeled with Ag NPs functionalized with a secondary S. aureus aptamer, SA61. ${ }^{95}$ Magnetic separation of the complex, followed by resuspension in $\mathrm{HNO}_{3}$ for dissolving the $\mathrm{Ag}$ NPs allowed the use of differential pulse stripping voltammetry to detect the released $\mathrm{Ag}^{+}$, which correlates to the concentration of $S$. aureus. A detection limit down to $1 \mathrm{cfu} \mathrm{mL}^{-1}$ was achieved with this approach.

More lately, some work was dedicated to the development of an aptasensors for M. tuberculosis antigens. ${ }^{96-97}$ Bai proposed a coil-like fullerene-doped polyaniline hybrid modified with Au NPs and M. tuberculosis aptamer as a redox and amplification probe for the electrochemical detection of MPT64 antigen in an electrochemical sandwich assay. The proposed sensor displayed high selectivity and was successfully applied for serum analysis of tuberculosis patients. ${ }^{96}$

An interesting impedimetric apatsensor for the detection of E. coli $\mathrm{O} 157: \mathrm{H} 7$ was constructed by Brosel-Oliu et al. using three-dimensional interdigitated electrode arrays, consisting of $\mathrm{TaSi}_{2}$ electrodes modified with E. coli aptamers (Figure 7B). ${ }^{98}$ The sensor depicted excellent selectivity to E. coli $\mathrm{O} 157: \mathrm{H} 7$ with a detection limit of $290 \mathrm{cfu} \mathrm{mL}^{-1}$. Guo et al. achieved electrochemical detection of E. coli pathogens by peroxidase-mimicking DNAzyme (Figure 7C). ${ }^{99}$ An aptamer-prime probe containing anti-E. coli aptamer and a sequence complementary to a circular probe including two G-quadruplex units, was employed as recognition unit, triggering RCA-based polymerase elongation. In the presence of $E$. coli the formation of numerous G-quadruplex oligomers occurs, folding with the help of $\mathrm{K}^{+}$and hemin into Gquadruplex/hemin complexes This generates catalytic activity toward $\mathrm{H}_{2} \mathrm{O}_{2}$.

(A)

(a)

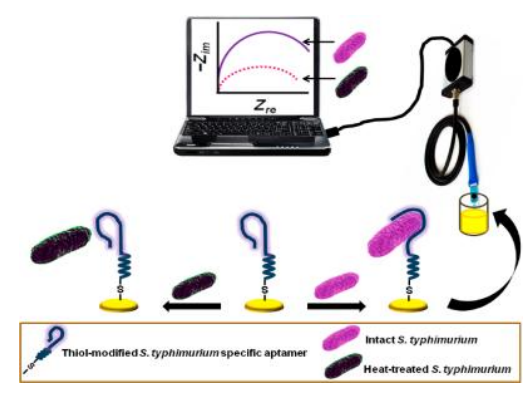

(b)

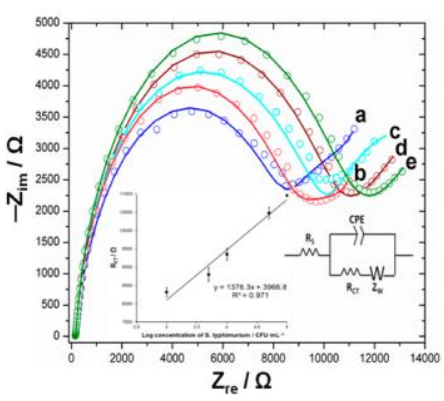

(B) 
(a)

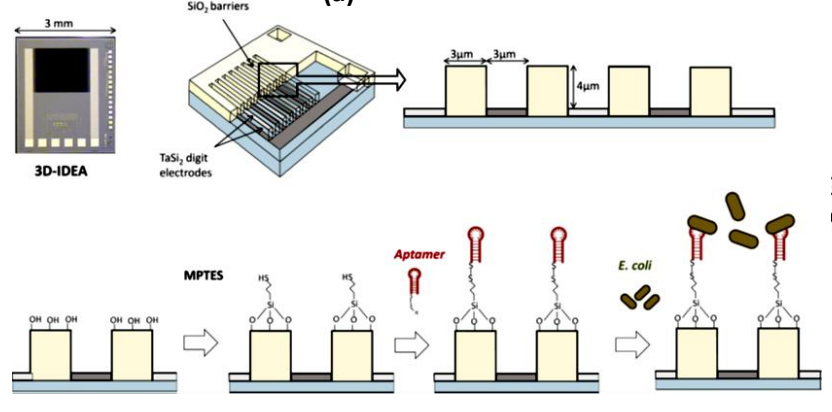

(b)

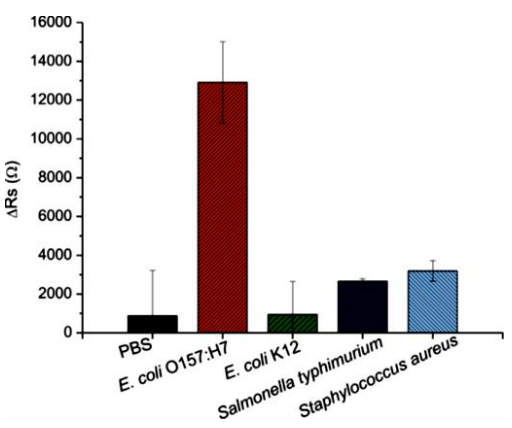

(C)

(a)

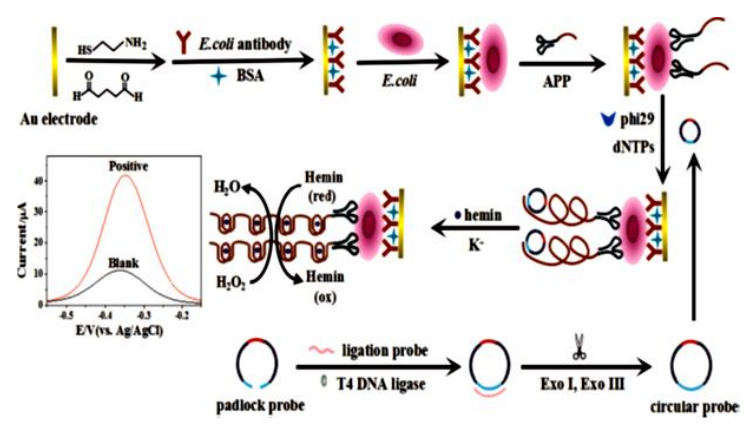

(b)

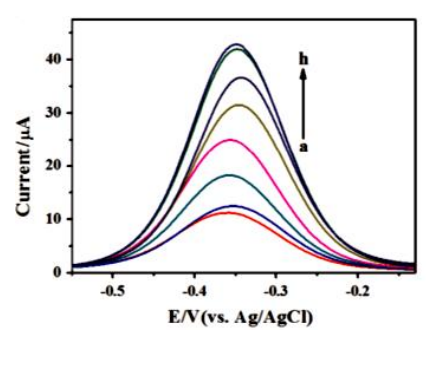

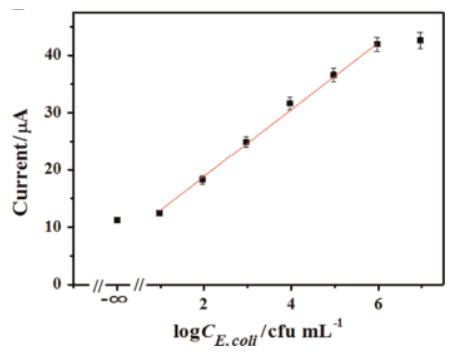

Figure 7: (A) (a) Diagram of an aptamer-based sensor for S. typhimurium; (b) Nyquist plot obtained using $1 \times 10^{3}$ (a), $0.4 \times 10^{4}$ (b), $1 \times 10^{4}$ (c), $0.5 \times 10^{5}$ (d), $1 \times 10^{5}$ (e) cfu $\mathrm{mL}^{-1}$ of $S$. typhimurium: the insets represent the modified Randers circuit applied to fit data as well as the calibration curve of the sensor (Reprint with permission from Ref. ${ }^{93}$; Copyright 2012, American Chemical Society); (B) (a) Image of 3D-interdigidated electrode and used bio-functionalization steps, (b) Evaluation of selectivity of the aptasensor for the detection of different bacteria strains and control in PBS without bacteria (Reprint with permission from Ref. ${ }^{98}$; Copyright 2018, Elsevier); (C) (a) Illustration of the electrochemical assay of E. coli detection based on RCA and DNAzyme amplification; (b) DPV responses to different concentrations of E. coli together with calibration curve.- Reprint with permission from Ref. ${ }^{99}$; Copyright 2016, Elsevier); 
Table 3. Aptamer-mediated electrochemical pathogen sensors.

\begin{tabular}{|c|c|c|c|c|c|}
\hline Pathogen & $\begin{array}{l}\text { Detection } \\
\text { Method }\end{array}$ & Sensitivity & $\begin{array}{l}\text { LOD } \\
\left(\text { cfu } \mathrm{mL}^{-1}\right)\end{array}$ & $\begin{array}{l}\text { Linear dynamic } \\
\text { range }\left(\mathrm{cfu} \mathrm{mL}^{-1}\right)\end{array}$ & Ref. \\
\hline E. coli & DPV & - & 8 & $9.4 \times 10^{0}-9.4 \times 10^{5}$ & 99,9 \\
\hline E. coli & Conductance & - & - & - & \\
\hline E. coli O157:H7 & EIS & $2591 \Omega / \log \mathrm{c}$ & 290 & $10^{2}-10^{6}$ & 100 \\
\hline E. coli O157:H7 & EIS & $16.1 \mathrm{~W} / \log \mathrm{c}$ & 4 & $5-100$ & 101 \\
\hline $\begin{array}{l}\text { E. coli } \\
\text { O78:K80:H11 }\end{array}$ & EIS & - & 10 & $10^{1}-10^{6}$ & 102 \\
\hline S. aureus & EIS & - & 10 & $10^{1}-10^{4}$ & 103 \\
\hline S. aureus & potentiometry & - & 800 & $2.4 \times 10^{3}-1 \times 104$ & 22 \\
\hline S. aureus & potentiometry & - & 1 & - & 20 \\
\hline S. aureus & EIS & - & 10 & $10^{1}-10^{6}$ & 104 \\
\hline S. aureus & DPV & - & 1 & $10^{1}-10^{6}$ & 95 \\
\hline S. aureus & potentiometry & - & $8 \times 10^{2}$ & - & 20 \\
\hline S. aureus & AS DPV & - & 1 & - & 95 \\
\hline S. typhimurium & DPV & $\begin{array}{l}100 \mathrm{~mA} \mathrm{~m}^{-2} / \\
\log \mathrm{c}\end{array}$ & 10 & $10^{1}-10^{8}$ & 105 \\
\hline S. typhimurium & DPV & $\begin{array}{l}0.55 \mathrm{~mA} \mathrm{~m}^{-2} / \\
\log \mathrm{c}\end{array}$ & 10 & $10^{1}-10^{6}$ & 106 \\
\hline S. typhimurium & CV, EIS & $841.4 \Omega / \log c$ & 1 & $6.5 \times 10^{2}-6.5 \times 10^{8}$ & 107 \\
\hline S. typhimurium & EIS & $0.1566 \Omega / \log c$ & 3 & $10^{2}-10^{8}$ & 108 \\
\hline S. typhimurium & EIS & $\begin{array}{l}0.116 \Delta \Omega / \log \\
\mathrm{C}\end{array}$ & 6 & $10^{1}-10^{8}$ & 23 \\
\hline S. typhimurium & EIS & $8.6 \Omega \log \mathrm{c}$ & 25 & $7.5 \times 10^{1}-7.5 \times 10^{5}$ & 104 \\
\hline $\begin{array}{l}\text { Clostridium } \\
\text { difficile toxin A }\end{array}$ & $\mathrm{CV}$ & $0.03 \mu \mathrm{A} / \mathrm{c}$ & $1 \mathrm{ng} \mathrm{mL} L^{-1}$ & $1-200 \mathrm{ng} \mathrm{mL}^{-1}$ & $\begin{array}{l}109 \\
\end{array}$ \\
\hline $\begin{array}{l}\text { M. tuberculosis } \\
\text { antigen }\end{array}$ & DPV & $\begin{array}{l}4.4 \mu \mathrm{A} / \log \mathrm{c}(\mathrm{fg} \\
\left.\mathrm{mL}^{-1}\right)\end{array}$ & $0.5 \mathrm{fg} \mathrm{mL}^{-1}$ & $1-5 \mathrm{fg} \mathrm{mL}^{-1}$ & 97 \\
\hline
\end{tabular}

\section{Antimicrobial peptides (AMP) based sensors}

Antimicrobial peptides are synthetic biomolecules targeted against the deactivation of bacteria. ${ }^{110}$ Most antimicrobial peptides are positively charged and composed of 10-50 amino acids with a molecular mass of 1-5 $\mathrm{kDa}$. Their positive charge initiates electrostatic interaction with the negatively charged cell membrane of bacteria, but not with zwitterionic membranes of mammalian cells. This selectivity allows their employment as potential recognition elements for electrochemical detection of pathogens. There are several modes of action of AMPs notated as barrel-starve model, carpet model, toroidal model or detergent model. ${ }^{111}$ In the barrel-starve 
model, the AMP assumes an amphipathic conformation, where the hydrophobic part intermingles with the lipid acryl chains of the membranes. In the carpet model, the peptides are attracted by the anionic phospholipids covering the bacterial surface membrane until saturation with subsequent solubility of the bacterial membrane. The toroidal model is based on the insertion of the peptide parallel to the membrane, causing cell death; the detergent model is grounded on membrane solubilization and cell death. It was from the seminal work of Kulagina in 2005, who highlighted the potential of AMP magainin I (GIGKFLHSAGKFGKAFVGEIMKS), immobilized on glass, to act as a specific recognition element for E. coli O157:H7 and $S$. typhimuriym in a fluorescence based assay, that AMPs got accepted as bioreceptors for sensors (Table 4). ${ }^{112}$ One of the first electrochemical based sensors using AMPs is that of Manoor et al. ${ }^{113-114}$ who demonstrated the ability of magainin I modified interdigitated electrodes for the detection of E. coli $\mathrm{O} 157: \mathrm{H} 7$ and S. typhimuriym by EIS. Another impedimetric sensor was developed by $\mathrm{Li}$ et al. using gold electrodes modified with lipoic acid to which magainin I modified with ferrocene tag was linked covalently using EDC/NHS chemistry. ${ }^{115}$ The sensor

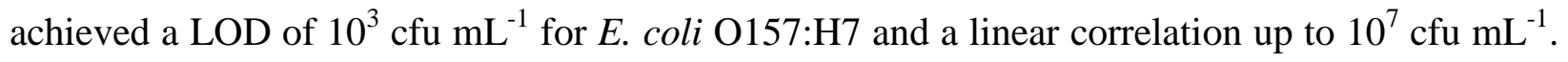
At the same time some other impedimetric microsensors for Listeria monocytogenes using leucocin A, ${ }^{116}$ as well as for Pseudomonas aeruginosa and Streptococcus mutans using synthetic peptides such as G10KHc AMP and C16G2cys were established. ${ }^{117}$ In the case of the $L$. monocytogenes (Figure $\mathbf{8 A}$ ), the antimicrobial peptide was covalently immobilized on microelectrodes via interaction between the carboxylic acid of the peptide and the free amines of a pre-attached thiolated linker. ${ }^{116}$ This study underlined the believe that short peptide ligands from bacteriocins offer high selectivity in bacteria sensing with detection limits of 1 cell/ $\mu \mathrm{L}$, a clinically relevant limit. More recently, human lactoferrin modified interdigitated electrode arrays was used to detect $S$. sanguinies in artificial saliva by impedimetric sensing. ${ }^{118}$

(A) 
(a)

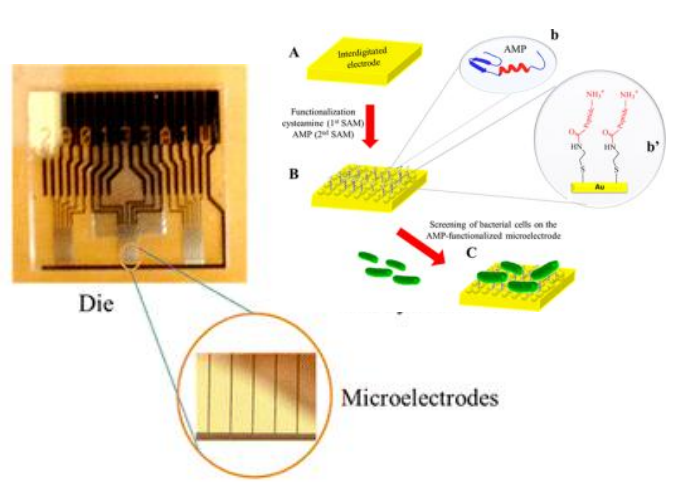

(B)

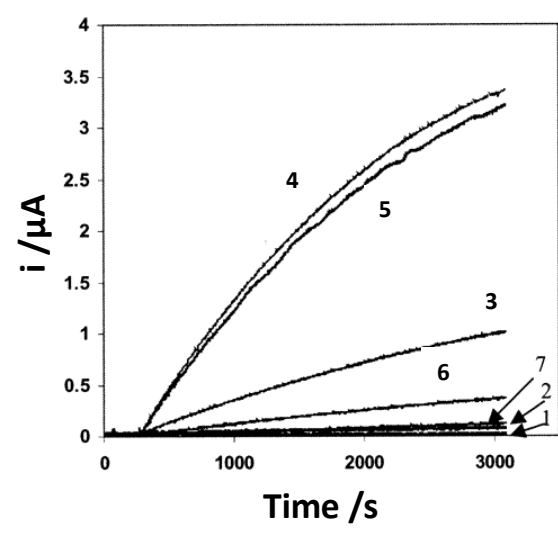

(b)
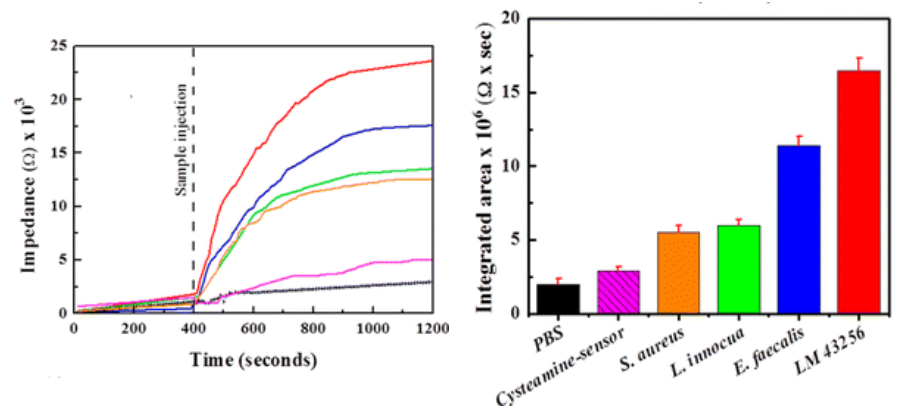

(C)
1 no phage

$21.25 \mathrm{cfu} \mathrm{mL}^{-1}$

$312.5 \mathrm{cfu} \mathrm{mL}^{-1}$

$4125 \mathrm{cfu} \mathrm{mL}^{-1}$

$51250 \mathrm{cfu} \mathrm{mL}^{-1}$

$612500 \mathrm{cfu} \mathrm{mL}^{-1}$

$7125000 \mathrm{cfu} \mathrm{mL}^{-1}$

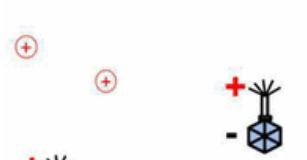

$\oplus$

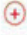

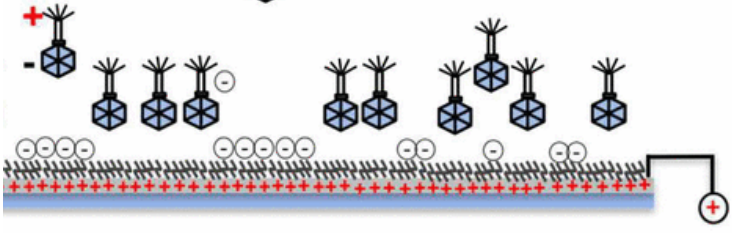

(D)

(a)
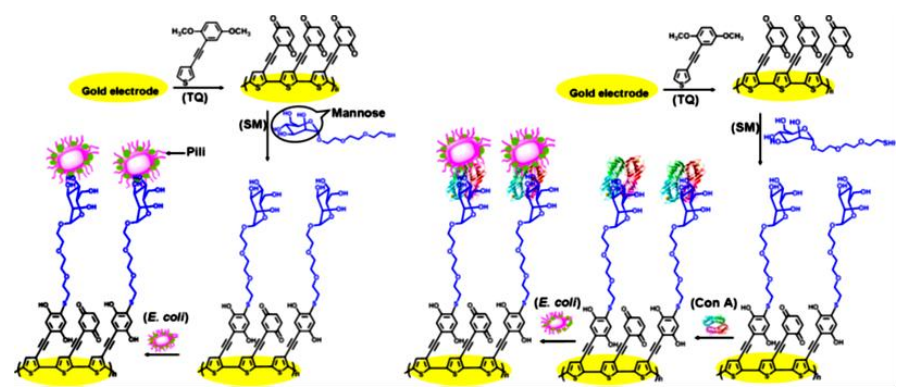

(b)

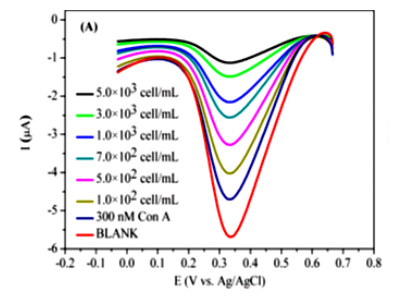

Figure 8. (A) (a) AMP-based biosensor using microelectrode array, (b) Impedimetric response of the AMP sensor to various bacterial species $\left(10^{3} \mathrm{cfu} \mathrm{mL}^{-1}\right)$ at $100 \mathrm{~Hz}$ (Reprint with permission from Ref. ${ }^{116 ;}$ Copyright 2014, American Chemical Society); (B) Response of $\beta$-Dgalactosidases activity due to $E$. coli $\left(2.5 \times 10^{4} \mathrm{cfu} \mathrm{mL}^{-1}\right)$ infected with phage 1 vir (0-1.25-12.5125-1250-12500 pfu mL ${ }^{-1}$ ) (Reprint with permission from Ref. ${ }^{119}$; Copyright 2003, American Chemical Society); (C) Schematic description of charge-directed bacteriophage immobilization (Reprint with permission from Ref. ${ }^{120}$ Copyright 2017, American Chemical Society); (D) (a) 
Different modes of $E$. coli detection based on polythiophene modified electrode with linked glycans (left) for Pili-Mannose Binding and ConA modified interfaces for Con A-mediated $E$. coli binding (right), (b) Square wave voltammetry responses after incubation with Con A and $E$. coli (Reprint with permission from Ref. ${ }^{121 ;}$ Copyright 2015, American Chemical Society).

Table 4. Antimicrobial peptides-mediated electrochemical pathogen sensors.

\begin{tabular}{|c|c|c|c|c|c|}
\hline Pathogen & $\begin{array}{l}\text { Detection } \\
\text { Method }\end{array}$ & Sensitivity & $\begin{array}{l}\text { LOD } \\
\left(\mathrm{cfu} \mathrm{mL}^{-1}\right)\end{array}$ & $\begin{array}{l}\text { Linear dynamic } \\
\text { range }\left(\mathrm{cfu} \mathrm{mL}^{-1}\right)\end{array}$ & Ref. \\
\hline \multicolumn{6}{|c|}{ Antimicrobial peptides (AMP) based sensors } \\
\hline E. coli $\mathrm{O} 157: \mathrm{H} 7$ & EIS & & 1000 & $10^{3}-10^{7}$ & 115 \\
\hline $\begin{array}{l}\text { E. coli } \mathrm{O} 157: \mathrm{H} 7 \\
\text { S. typhimurium }\end{array}$ & EIS & & 1000 & & 113 \\
\hline S. typhimuriym & EIS & & 1000 & & 114 \\
\hline S. sanguinis & EIS & $3.45 \Omega / \log \mathrm{c}$ & 35 & $10^{1}-10^{5}$ & 118 \\
\hline L. monocytogenes & EIS & & 1000 & $10^{3}-10^{6}$ & 116 \\
\hline $\begin{array}{l}\text { P. aeruginosa } \\
\text { Streptococcus }\end{array}$ & & & 100000 & & 117 \\
\hline \multicolumn{6}{|c|}{ Lectin based sensors } \\
\hline \multirow[t]{2}{*}{ E. coli } & EIS & $3650 \Omega / \log \mathrm{c}$ & 75 & $10^{2}-10^{5}$ & 122 \\
\hline & & & 600 & & 123 \\
\hline $\begin{array}{l}\text { Sulfate reducing } \\
\text { bacteria }\end{array}$ & EIS & & 1.8 & $1.8^{*} 10^{0}-1.8^{*} 10^{7}$ & 84 \\
\hline E. coli & EIS & & 5000 & $5 * 10^{3}-5^{*} 10^{7}$ & 124 \\
\hline \multicolumn{6}{|l|}{ Bacteriophages } \\
\hline E. coli MG1655 & $\mathrm{CA}$ & & 100 & $10^{2}-10^{5}$ & 119 \\
\hline E. coli TG1 & $\mathrm{CA}$ & & \begin{tabular}{|l|l|}
1 \\
\end{tabular} & $10^{0}-10^{3}$ & 125 \\
\hline E. cloi K12 & EIS & $0.147 \Omega / \log c$ & 20 & $10^{2}-10^{8}$ & 126 \\
\hline Salmonella & $\mathrm{CA}$ & & 4 & $10^{0}-10^{5}$ & 127 \\
\hline E. cloi K12 & EIS & $1.87 \Omega / \log \mathrm{c}$ & 1000 & $10^{3}-10^{6}$ & 120 \\
\hline \multicolumn{6}{|l|}{ Carbohydrates } \\
\hline E. coli ORN 178 & EIS & & 120 & $1.2 \times 10^{2}-2.5 \times 10^{3}$ & 128 \\
\hline E. coli & EIS & & 1700 & $5 \times 10^{4}-5 \times 10^{7}$ & 121 \\
\hline
\end{tabular}

\section{Bacteriophage based sensors}

Bacteriophages (called simply phages) are natural host-specific nanostructured particles. Important advantages of using bacteriophages as ligands is linked to the fast and cheap production. Phages are stable at different $\mathrm{pH}$ and temperature. They bind to bacterial surface receptors and insert the genetic material inside the bacteria. ${ }^{129}$ The replicated virions are ultimately released, destroying the bacteria and infecting other host cells. Diagnostics based on 
bacteriophage is attractive in addition due to the high specificity of phages. towards cell-surface proteins, pili, lipopolysaccharides, lipoproteins. ${ }^{129}$ Expression of bioluminescence genes, encoded by bacteriophages (lux-bacteriophage strategy), fluorescence-taged phages which can be combined with immune magnetic separation (label phage strategy), phage amplification strategies as well as or phage mediated bacterial lysis are detection possibilities. One of the first examples, like the work by Rishpon and co-workers, ${ }^{119,}{ }^{125}$ uses phage-specific identification, release of an enzymatic cell marker, following cell lysis for analysis. In their work, they electrochemically determined using screen printed electrodes, biased at $220 \mathrm{mV}$, the enzymatic activity of $\alpha$-D-galactosidases, released from E. coli K12 and MG1655 cells infected by plaque forming units of virulent $\lambda$ phage, using p-aminophenyl- $\beta-D$-galactopyranoside (PAPG) as substrate (Figure 8B). A similar approach, based on the electrochemical detection of alkaline phosphatase, was also reported. Infection of E. coli TG-1 with a modified phage, phagemid M13KO7 and pFLAG-ATS-BAP, a gene encoding for alkaline phosphatase, results in the formation of alkaline phosphatase in the space that separates the outer plasma membrane from the cell wall of E. coli. The porosity of the cell wall allows p-aminophenol phosphate to enter, facilitating the detection of the activity of the reporter enzyme amperometrically. ${ }^{125}$ Next to these assays, surface immobilization of bacteriophages opens up avenues for the development of biosensing platforms. This necessitates however an orientation controlled immobilization, as bacteriophages recognize bacteria via their tail spike proteins.

Different to these works, Shabani et al. ${ }^{126}$ studied covalent immobilization of wild-type T4 bacteriophages onto carboxylic acid modified screen-printed electrodes through EDC/NHS amine bond formation. EIS was used to follow the T4 phages-induced lyse of E. coli 12 within a period of 40-60 min. After an initial increase in impedance for the first $20 \mathrm{~min}$, attributed to the diffusion of bacteria to the phage-modified electrode, a decrease in impedance was recorded and correlates to bacteria lysis. A linear relation between $E$. coli concentrations and impedance in the range of $10^{2}-10^{8} \mathrm{cfu} \mathrm{mL}^{-1}$ was attained, while no significant changes were observed in the presence of Salmonella. More recently, Pividori and co-workers ${ }^{127}$ used magnetic particles covalently modified with bacteriophage P22 specific to Salmonella for phagomagnetic bacteria separation. DNA amplification of the captured bacteria was performed by double-tagged PCR (biotin and digoxigenic signal primer to achieve enzymatic detection via anti-Dig-HRP receptors) through immobilization of biotin-labeled double-tagged amplicon to streptavidin 
particles, magnetic capture onto glassy carbon electrodes followed by labeling with anti-DigHRP receptors and amperometic detection of formed hydrogen peroxide. The method proved to be able to detect $3 \mathrm{cfu} \mathrm{mL}^{-1}$ of Salmonella in $4 \mathrm{~h}$.

Some reports concern oriented phage immobilization using charge-directed immobilization ${ }^{120,}$ ${ }^{130}$. Most phages show an overall negative charge, with a negatively charged head and positively charged tail. This charge variance was used tor controlled immobilization via electrostatic interactions and electrophoretic deposition approaches. ${ }^{120,130,131}$ Zhou et al. described most recently an electrochemical biosensor for $E$. coli B detection using $\mathrm{T} 2$ bacteriophages immobilized on polyethyleneamine-modified carbon nanotubes deposited on glassy carbon electrodes (Figure 8C). ${ }^{120}$ Using electrochemical impedance spectroscopy selective binding towards the B strain of $E$. coli was achieved with a detection limit of $10^{3} \mathrm{cfu} \mathrm{mL}^{-1}$.

\section{Lectin-based sensors}

Next to the discussed surface ligands, lectins are known to bind strongly to specific carbohydrate functions on the surface of bacteria and are thus interesting candidates as molecular recognition elements. They are rather easy to produce compared to antibodies and have intrinsic stability. Furthermore, the molecular size of lectins is small resulting in high surface densities of sensing elements with higher sensitivity and low non-specific adsorption. ${ }^{124}$ Conconcanavalin A (Con A) linking to bacteria with complementary carbohydrate pocket has been mainly used. ${ }^{122,123,132} \mathrm{~A}$ lectin-based displacement sensor for E. coli using ferrocene boronic acid as reporter was reported for example showing a LoD of 600 cells $\mathrm{cfu} \mathrm{mL}^{-1}{ }^{123}$ Immobilization of Con $\mathrm{A}$ on 11mercaptoundecanoic acid modified gold electrodes was applied for the rapid detection of sulfatereducing bacteria. ${ }^{84}$ More recently, an impedimetric sensor consisting of ConA covalently linked to gold interfaces modified with MUA and dithiothreitol and $\mathrm{Fe}(\mathrm{CN})_{6}{ }^{-3 / 4}$ as redox probe, allowed to detect $E$. coli with a detection limit of $75 \mathrm{cfu} \mathrm{mL}^{-1}$ over a linear range of $10^{2}-10^{5} \mathrm{cfu}$ $\mathrm{mL}^{-1}$ using EIS. ${ }^{122}$

\section{Glycan based sensors}

One of the first carbohydrate based electrochemical sensor is that of Heinemann and coworkers. ${ }^{128}$ Mannoside and galactoside were immobilized on gold disk electrodes using a SAM via a spacer terminated with a thiol functionality to link the ligand to read out E. coli ORN 178 
impedimetrically. ${ }^{128} \mathrm{Ma}$ et al. ${ }^{121}$ reported on quinone modified polythiophene interfaces which were further glycosylated for bacterial detection (Figure 8D) with a LOD to 25 cells/mL over a wide linear range of $10^{3}-10^{7}$ for pili-mannose and $10^{2}-10^{2}$ for ConA. ${ }^{121}$

\section{Conclusion and perspectives}

The recognition of bacteria and viruses remains challenging and important for ensuring food safety, controlling water and soil pollution, preventing disease outbreaks and ensuring the health state of humans. To date, a plethora of electrochemical sensors for pathogen detection are available. A large amount of these sensors are in line with the main requirements for sensitive, specific and fast analysis. However, only a handful shows high reproducibility and reliable sensing in more complex media than aqueous solutions. Indeed, a major challenge is posed by the potential interfering species such as particulate matter, organic/inorganic contaminants and other biomolecules limiting the life time of the sensors, diminishing the sensitivity of the sensor and ultimately the reliability of the read out. Sensing ligands such as antibodies operate optimally under stringent environmental conditions and may be prone to degradation and thus lowering the selectivity of the sensor. These different challenges have been addressed by taking advantage of robust molecular detection schemes and by replacing natural receptors with aptamers and synthetic templates such as imprinted polymers. The use of bacteriophages as biorecognition elements is an interesting alternative for electrochemical bacteria sensing, but still in its infancy. This is mainly due to a limited range of commercially available bacteriophages, but also it is only lately that dense and well-oriented layers of bacteriophages could be immobilized onto solid transducers such gold. ${ }^{130}$

Currently, the number of strategies proposed for the immobilization of pathogen specific ligands onto electrodes is quite limited. This field might be exploited much further in the future as it is one of the crucial steps in any biosensing based format. While these issues apply to any pathogen sensor, it is evident that the best qualified pathogen sensors should satisfy different requirements such as low cost, portability, miniaturization, easy to use with the possibility of multiplexing.

With the speedy evolution of nanotechnology, an extensive range of nanomaterials are developed for sensing. Integration of these materials and 3D architectures onto electrical interfaces allowed obtaining high sensitive sensors. Among these nanomaterials carbon nanotubes and notably reduced graphene oxide have attracted large interest. Detection using graphene coated sensors 
represents an attractive technology and has been proposed by several different research teams in the past The 2D nanostructure of graphene is advantageous for the integration of a high density of ligands in easy manner, often relying on non-covalent $\pi-\pi$ stacking and electrostatic interactions. However, this large surface area can also be a limiting factor, fostering interactions with blood serum components and formation of precipitates with red blood cells or serum proteins when sensors are immerged into real samples. A key design feature for real applications is thus to minimize non-specific interactions and improving the non-fouling properties of graphene based electrodes. The possibility of integration of functionalized rGO such as rGO/PEI by electrophoretic deposition, followed by modification with bacterial ligand and integration of anti-fouling units such as pyrene-PEG units using the $\pi-\pi$ stacking capacity of rGO resulted for example in highly sensitive and selective electrochemical sensor for uropathogenic E. coli UTI89 ${ }^{21}$ without any amplification. Other nanomaterials such as metallic nanoparticles, notably gold nanoparticles, but also carbon-based nanomaterials have been used not for electrode surface modification but also as electrochemical amplification agents to increase the sensitivity of electrochemical sensors. These sensing schemes are mainly based on sandwich assays, which indeed result mostly in excellent sensing parameters. Their multi-step approach including the synthesis of several nanomaterials together with higher costs due to the sandwich format limit their practical application.

What are the current alternative to electrochemical sensors? The main sensing platforms in competition with electrochemical transducers are currently optical pathogen sensors taking advantage of new optical active nanostructures, new fluorescent nanomaterials (up converted particles, quantum dots, etc) as well as surface resonance technology, optical-fiber and other miniaturizable optical technology to design portable devices. While for a long time they have suffered from detection limits being too high for sensitive pathogen analysis, progress in optical technologies made them increasingly competitive with electrochemical read outs. The often remain costly due to certain optical requirements. Both techniques should be seen as complementary and the adapted method should be reliable and selective to a particular pathogen of interest. Electrical detection using field effect transistors is another appealing alternative. However, these sensors when it comes to pathogen detection and real sample analysis are still in their infancy; more research efforts on anti-fouling strategies by keeping the advantages of an electrical read out need to be addressed to drive these devices to a competing level. 


\section{Acknowledgements}

Financial support from the Centre National de la Recherche Scientifique (CNRS), the University of Lille, the Hauts-de-France region, the CPER "Photonics for Society", the EU union through the Marie Sklodowska-Curie action (H2020-MSCA-RISE-2015, PANG-690836) and the Agence Nationale de la Recherche (ANR) through FLAG-ERA JTC 2015-Graphtivity project are acknowledged.

\section{REFERENCES}

1. Dye, C., After 2015: infectious diseases in a new area of health and development. Phil. Trans. R. Soc. B 2014, 369, 20130426.

2. Douterelo, I.; Boxall, J. B.; Deines, P.; Sekar, R.; Fish, K. E.; Biggs, C. A., Methodological approaches for studing the microbial ecology of drinking water distribution systems. Water Res. 2014, 65, 134-156.

3. Behnam, F.; Vilcinsk, A.; Wagner, M.; Stoecker, K., A Straightforward DOPE (Double Labeling of Oligonucleotide Probes)-FISH (Fluorescence In Situ Hybridization) Method for Simultaneous Multicolor Detection of Six Microbial Populations. App. Environ. Microbiol. 2012, 78, 5138-5142.

4. Berney, M.; Hammes, F.; Bosshard, F.; Weilenmann, H.-U.; Egli, T., Assessment and Interpretation of Bacterial Viability by Using the LIVE/DEAD BacLight Kit in Combination with Flow Cytometry. App. Environ. Microbiol. 2007, 73, 3283.

5. Young, K. D., The selective value of bacterial shape. Microbiol. Mol. Biol Rev. 2006, 70 (3), 660-703.

6. Law, J. W.-F.; Ab Mutalib, N.-S.; Chan, K.-G.; Lee, L.-H., apid methods for the detection of foodborne bacterial pathogens: principles, applicaitons, advantages and mimitations. Front. Microbiol. 2015, 5, 1.

7. Hamels, S.; Gala, J. L.; Dufour, S.; Vannuffel, P.; Zammatteo, N.; Remacle, J., Consensus PCR and Microarray for Diagnosis of the Genus Staphylococcus, Species, and Methicillin Resistance. Biotechniques 2001, 31, 1364-1372.

8. Cho, J.-C.; Tiedje, J. M., Bacterial Species Determination from DNA-DNA Hybridization by Using Genome Fragments and DNA Microarrays. Appl. Environ. Microbiol. 2001, 67, 3677-3682.

9. Kalyuzhnaya, M. G.; Lidstrom, M. E.; Chistoserdova, L., Real-time detection of actively metabolizing microbes by redox sensing as applied to methylotroph populations in Lake Washington. ISME J. 2008, 2 (7), 696-706.

10. Wun, J.; Zhou, S.; Chen, J., Colorimetric detection of Shewanella oneidensis based on immunomagnetic capture and bacterial intrinsic peroxidase activity. Sci. Rep. 2014, 4, 5191-5197.

11. J. W. Costerton; P. S. Stewart; Greenberg, E. P., Bacterial Biofilms: A Common Cause of Persistent Infections. Science 1999, 284, 1318-1322. 
12. Lazcka, O.; Del Campo, F. J.; Munoz, F. X., Pathogen detection: A perspective of traditional methods and biosensors. Biosens Bioelectron. 2007, 22 (7), 1205-1217.

13. Yang, L.; Li, Y.; Erf, G. F., Interdigitated Array Microelectrode-Based Electrochemical Impedance Immunosensor for Detection of Escherichia c oli O157: H7. Anal. Chem. 2004, 76 (4), 1107-1113.

14. dos Santos, M.; Barreiros, M.; Sporer, C.; Sanvicens, N.; Pascual, N.; Errachid, A.; Martinez, E.; Marco, M.-P.; Teixeira, V.; Samiter, J., Detection of pathogenic Bacteria by Electrochemical Impedance Spectroscopy: Influence of the immobilization strategies on the sensor performance. Procedia Chem. 2009, 1 (1), 1291-1294.

15. Huang, T. T.; Sturgis, J.; Gomez, R.; Geng, T.; Bashir, R.; Bhunia, A. K.; Robinson, J. P.; Ladisch, M. R., Composite surface for blocking bacterial adsorption on protein biochips. Biotechnol. Bioeng. 2003, 81 (5), 618-624.

16. Ulmann, A., Formation and Structure of Self-Assembled Monolayers. Chem. Rev. 1996, 96, 1533-1554.

17. Geng, P.; Zhang, X.; Meng, W.; Wang, Q.; Zhang, W.; Jin, m.; Feng, Z.; Wu, Z., Selfassembled monolayers-based immunosensor for detection of Escherichia coli using electrochemical impedance spectroscopy. Electrochim. Acta. 2008, 53, 4663-4668.

18. Liao, J. C.; Mastali, M.; Gau, V.; Suchard, M. A.; Møller, A. K.; Bruckner, D. A.; Babbitt, J. T.; Li, Y.; Gornbein, J.; Landaw, E. M., Use of electrochemical DNA biosensors for rapid molecular identification of uropathogens in clinical urine specimens. J. Clin. Microbiol. 2006, 44 (2), 561-570.

19. Skottrup, P. D.; Nicolaisen, M.; Justesen, A. F., Towards on-site pathogen detection using antibody-based sensors. Biosens Bioelectron. 2008, 24 (3), 339-348.

20. Hernández, R.; Vallés, C.; Benito, A. M.; Maser, W. K.; Rius, F. X.; Riu, J., Graphenebased potentiometric biosensor for the immediate detection of living bacteria. Biosens. Bioelectron. 2014, 54, 553-557.

21. Jijie, R.; Kahlouche, K.; Barras, A.; Yamakawa, N.; Bouckaert, J.; Gharbi, T.; Szunerits, S.; Boukherroub, R., Reduced graphene oxide/polyethylenimine based immunosensor for the selective and sensitive electrochemical detection of uropathogenic Escherichia coli. Sens. Actuator B 2018, 260, 255-263.

22. Zelada-Guillén, G. A.; Sebastián-Avila, J. L.; Blondeau, P.; Riu, J.; Rius, F. X., Label-free detection of Staphylococcus aureus in skin using real-time potentiometric biosensors based on carbon nanotubes and aptamers. Biosens Bioelectron. 2012, 31 (1), 226-232.

23. Bagheryan, Z.; Raoof, J.-B.; Golabi, M.; Turner, A. P.; Beni, V., Diazonium-based impedimetric aptasensor for the rapid label-free detection of Salmonella typhimurium in food sample. Biosens Bioelectron. 2016, 80, 566-573.

24. Lian, Y.; He, F.; Wang, H.; Tong, F., A new aptamer/graphene interdigitated gold electrode piezoelectric sensor for rapid and specific detection of Staphylococcus aureus. Biosens Bioelectron. 2015, 65, 314-319.

25. Altintas, Z.; Gittens, M.; Guerreiro, A.; Thompson, K.-A.; Walker, J.; Piletsky, S.; Tothill, I. E., Detection of Waterborne Viruses Using High Affinity Molecularly Imprinted Polymers. Anal. Chem. 2015, 87, 6801-6807.

26. Chen, S.; Chen, X.; Zhang, L.; Gao, J.; Ma, Q., Electrochemiluminescence detection of Escherichia coli O157: $\mathrm{H} 7$ based on a novel polydopamine surface imprinted polymer biosensor. ACS App. Mater. Interfaces 2017, 9 (6), 5430-5436. 
27. Golbi, M.; Kuralay, F.; Jager, E. W.; Beni, V.; Turber, A. P., Electrochemical bacterial detection using poly(3-aminophenylboronic acid)-based imprinted polymer. Biosens. Bioelectron. 2017, 93, 87-93.

28. Jiang, H.; Jiang, D.; Shao, J.; Sun, X., Magnetic molecularly imprinted polymer nanoparticles based electrochemical sensor for the measurement of Gram-negative bacterial quorum signaling molecules (N-acyl-homoserine-lactones). Biosens Bioelectron. 2016, 75, 411-419.

29. Luo, C.; Lei, Y.; Yan, L.; Yu, T.; Li, Q.; Zhang, D.; Ding, S.; Ju, H., A Rapid and Sensitive Aptamer-Based Electrochemical Biosensor for Direct Detection of Escherichia Coli O111. Electroanalysis 2012, 24 (5), 1186-1191.

30. Roy, E.; Patra, S.; Tiwari, A.; Madhuri, R.; Sharma, P. K., Single cell imprinting on the surface of $\mathrm{Ag}-\mathrm{ZnO}$ bimetallic nanoparticle modified graphene oxide sheets for targeted detection, removal and photothermal killing of E. Coli. Biosens Bioelectron. 2017, 89, 620626.

31. Wang, Q.; Kaminska, I.; Niedziolka-Jonsson, J.; Opallo, M.; Li, M.; Boukherroub, R.; Szunerits, S., Sensitive sugar detection using 4-aminophenylboronic acid modified graphene. Biosens Bioelectron. 2013, 50, 331-337.

32. Lv, X.; Ge, W.; Li, Q.; Wu, Y.; Jiang, H.; Wang, X., Rapid and ultrasensitive electrochemical detection of multidrug-resistant bacteria based on nanostructured gold coated ITO electrode. ACS App. Mater. Interfaces 2014, 6 (14), 11025-11031.

33. Ligaj, M.; Tichoniuk, M.; Gwiazdowska, D.; Filipiak, M., Electrochemical DNA biosensor for the detection of pathogenic bacteria Aeromonas hydrophila. . Electrochim. Acta. 2014, 128, 67-74.

34. Nordin, N.; Yusof, N. A.; Abdullah, J.; Radu, S.; Hushiarian, R., A simple, portable, electrochemical biosensor to screen shellfish for Vibrio parahaemolyticus. AMB Express 2017, 7 (1), 41.

35. Díaz-Serrano, M.; Rosado, A.; Santana, D.; Vega, E.; Guadalupe, A. In Synthesis, characterization and use of Ru-Fc intercalation complex as an electrochemical label for the detection of pathogen-DNA, J. Phys. Conf. Ser., IOP Publishing: 2013; p 012008.

36. Dong, S.; Zhao, R.; Zhu, J.; Lu, X.; Li, Y.; Qiu, S.; Jia, L.; Jiao, X.; Song, S.; Fan, C.; Hao, R.; Song, H., Electrochemical DNA Biosensor Based on a Tetrahedral Nanostructure Probe for the Detection of Avian Influenza A (H7N9) Virus. . ACS App. Mater. Interfaces 2015, 7, 8834-8842.

37. Ahmed, M. U.; Nahar, S.; Safavieh, M.; Zourob, M., Real-time electrochemical detection of pathogen DNA using electrostatic interaction of a redox probe. Analyst 2013, 138 (3), 907-915.

38. Abdalhai, M. H.; Maximiano Fernandes, A.; Bashari, M.; Ji, J.; He, Q.; Sun, X., Rapid and Sensitive Detection of Foodborne Pathogenic Bacteria (Staphylococcus aureus) Using an Electrochemical DNA Genomic Biosensor and Its Application in Fresh Beef. J. Agric. Food Chem. 2014, 62 (52), 12659-12667.

39. Barreda-Garcia, S.; Miranda-Castro, R.; de-los-Santos-Alvarez, N.; Miranda-Ordieres, A. J.; Lobo-Castanon, M. J., Comparison of isothermal helicase-dependent amplification and PCR for the detection of Mycobacterium tuberculosis by an electrochemical genomagnetic assay. Anal. Bioanal. Chem. 2016, 408, 8603-8610. 
40. del Rio, J. S.; Svobodova, M.; Bustos, P.; Conejeros, P.; O'Sullivan, C. K., Electrochemical detection of Piscirickettsia salmonis genomic DNA from salmon samples using solid-phase recombinase polymerase amplification. Anal. Bioanal. Chem. 2016, 408, 8611-8620.

41. Miodek, A.; Mejri, N.; Gomgnimbou, M.; Sola, C.; Korri-Youssoufi, H., E-DNA sensor of Mycobacterium tuberculosis based on electrochemical assembly of nanomaterials (MWCNTs/PPy/PAMAM). Anal. Chem. 2015, 87 (18), 9257-9264.

42. Guo, Y.; Wang, Y.; Liu, S.; Yu, J.; Wang, H.; Liu, X.; Huang, J., Simultaneous voltammetric determination of E. coli and $\mathrm{S}$. typhimurium based on target recycling amplification using self-assembled hairpin probes on a gold electrode. Microchim. Acta 2017, 184, 745-752.

43. Thuy, N. T.; Tam, P. D.; Tuan, M. A.; Le, A.-T.; Van Thu, V.; Van Hieu, N.; Chien, N. D., Detection of pathogenic microorganisms using biosensor based on multi-walled carbon nanotubes dispersed in DNA solution. Curr. Appl. Phys. 2012, 12 (6), 1553-1560.

44. Tiwari, I.; Singh, M.; Pandey, C. M.; Sumana, G., Electrochemical genosensor based on graphene oxide modified iron oxide-chitosan hybrid nanocomposite for pathogen detection. Sens. Actuator B 2015, 206, 276-283.

45. Gau, J., Jr.; Lan, E. H.; Dunn, B.; Ho, C.-M.; Woo, J. C. S., A MEMS based amperometric detector for E. Coli bacteria using self-assembled monolayers. Biosens Bioelectron. 2001, 16 (9), 745-755.

46. Jiang, D.; Liu, F.; Liu, C.; Liu, L.; Pu, X., An Electrochemical Sensor Based on Allosteric Molecular Beacons for DNA Detection of Escherichia coli O157: H7. Int. J. Electrochem. Sci. 2013, 8, 9390-9398.

47. Redondo-Marugan, J.; Petit-Dominguez, M.; Casero, E.; Vázquez, L.; García, T.; ParraAlfambra, A.; Lorenzo, E., Sol-gel derived gold nanoparticles biosensing platform for Escherichia coli detection. Sens. Actuator B 2013, 182, 307-314.

48. Walter, A.; Wu, J.; Flechsig, G.-U.; Haake, D. A.; Wang, J., Redox cycling amplified electrochemical detection of DNA hybridization: application to pathogen E. coli bacterial RNA. Anal. Chim. Acta 2011, 689 (1), 29-33.

49. Patel, M. K.; Gonzalez, R.; Halford, C.; Lewinski, M. A.; Landaw, E. M.; Churchill, B. M.; Haake, D. A., Target-specific capture enhances selectivity of electrochemical detetction of bacterial pathogens. J. Clin. Microbiol. 2011, 4293-4296.

50. Pei, Q.; Wang, Y.; Liu, S.; Qin, Y.; Leng, X.; Cui, X.; Huang, J., Exonuclease III-aided autonomous cascade signal amplification: a facile and universal DNA biosensing platform for ultrasensitive electrochemical detection of S. typhimurium. New J. Chem. 2017, 41 (15), 7613-7620.

51. Li, Q.; Cheng, W.; Zhang, D.; Yu, T.; Yin, Y.; Ju, H.; Ding, S., Rapid and sensitive strategy for Salmonella detection using an InvA gene-based electrochemical DNA sensor. Int. J. Electrochem. Sci. 2012, 7 (1), 844-856.

52. Kuan, G. C.; Sheng, L. P.; Rijiravanich, P.; Marimuthu, K.; Ravichandran, M.; Yin, L. S.; Lertanantawong, B.; Surareungchai, W., Gold-nanoparticle based electrochemical DNA sensor for the detection of fish pathogen Aphanomyces invadans. Talanta 2013, 117, 312317.

53. Patel, M. K.; Singh, J.; Singh, M. K.; Agrawal, V. V.; Ansari, S.; Malhotra, B., Tin oxide quantum dot based DNA sensor for pathogen detection. J. Nanosci. Nanotechnol. 2013, 13 (3), 1671-1678. 
54. Wang, J.; Leong, M. C.; Leong, E. Z. W.; Kuan, W. S.; Leong, D. T., Clinically Relevant Detection of Streptococcus pneumoniae with DNA-Antibody Nanostructures. . Anal. Chem. 2017, 89, 6900-6906.

55. Li, X.; Scida, K.; Crooks, R. M., Detection of hepatitis B virus DNA with a paper electrochemical sensor. Anal. Chem. 2015, 87 (17), 9009-9015.

56. Byrne, B.; Stack, E.; Gilmartin, N.; O’Kennedy, R., Antibody-based sensors: principles, problems and potential for detection of pathogens and associated toxins. Sensors 2009, 9 (6), 4407-4445.

57. Wang, Y.; Ye, Z.; Ying, Y., New Trends in Impedimatricc VioSensros for teh Detection of Foodborn Pathogenic Bacteria. Sensors 2012, 12, 3449-3471.

58. Cady, N. C.; Vincenzina Fusco; Giuseppe Maruccio; Elisabetta Primiceri; Batt, C. A., Micro- and nanotechnology-based approaches to detect pathogenic agents in food. In Nanobiosensors, Acadmeic press: 2017; pp 475-510.

59. Gehring, A. G. e. a., Antibody Microarray Detection of Escherichiacoli O157:H7: Quantification, Assay Limitations, and Capture Efficiency. Anal. Chem. 2006, 78 (18).

60. Gehring, A. G.; Gerald Crawford, C.; Mazenko, R. S.; Van Houten, L. J.; Brewster, J. D., Enzyme-linked immunomagnetic electrochemical detection of Salmonella typhimurium. $J$. Immunol. Methods 1996, 195 (1), 15-25.

61. de Ávila, B. E.-F.; Pedrero, M.; Campuzano, S.; Escamilla-Gómez, V.; Pingarrón, J. M., Sensitive and rapid amperometric magnetoimmunosensor for the determination of Staphylococcus aureus. Anal. Bioanal. Chem. 2012, 403 (4), 917-925.

62. Ruan, C.; Yang, L.; Li, Y., Immunobiosensor Chips for Detection of Escherichia coli O157:H7 Using Electrochemical Impedance Spectroscopy. Anal. Chem. 2002, 74 (18), 4814-4820.

63. Setterington, E. B.; Alocilja, E. C., Electrochemical biosensor for rapid and sensitive detection of magnetically extracted bacterial pathogens. Biosensors 2012, 2 (1), 15-31.

64. Chowdhury, A. D.; De, A.; Chaudhuri, C. R.; Bandyopadhyay, K.; Sen, P., Label free polyaniline based impedimetric biosensor for detection of E. coli O157:H7 Bacteria. Sens. Actuator B 2012, 171-172, 916-923.

65. MacBeath, G.; Schreiber, S. L., Printing proteins as microarrays for high-throughput function determination. Science 2000, 289 (5485), 1760-1763.

66. Wan, Y.; Zhang, D.; Wang, Y.; Hou, B., A 3D-impedimetric immunosensor based on foam $\mathrm{Ni}$ for detection of sulfate-reducing bacteria. Electrochem. Commun. 2010, 12 (2), 288291.

67. Bhardwaj, J.; Devarakonda, S.; Kumar, S.; Jang, J., Development of a paper-based electrochemical immunosensor using an antibody-single walled carbon nanotubes bioconjugate modified electrode for label-free detection of foodborne pathogens. Sens. Actuator B 2017, 253, 115-123.

68. Fei, J.; Dou, W.; Zhao, G., Amperometric immunoassay for the detection of Salmonella pullorum using a screen-printed carbon electrode modified with gold nanoparticle-coated reduced graphene oxide and immunomagnetic beads. Microchim. Acta 2016, 183 (2), 757 764.

69. Maalouf, R.; Fournier-Wirth, C.; Coste, J.; Chebib, H.; Saïkali, Y.; Vittori, O.; Errachid, A.; Cloarec, J.-P.; Martelet, C.; Jaffrezic-Renault, N., Label-free detection of bacteria by electrochemical impedance spectroscopy: comparison to surface plasmon resonance. Anal. Chem. 2007, 79 (13), 4879-4886. 
70. Lu, L.; Chee, G.; Yamada, K.; Jun, S., Electrochemical impedance spectroscopic technique with a functionalized microwire sensor for rapid detection of foodbornepathogens. Biosens Bioelectron. 2013, 42, 492-495.

71. Li, L.; Chen, Z.; Wang, S.; Jin, X.; Yang, L.; Liu, G.; Zhao, J., Highly selective detection of Escherichia coli O157: $\mathrm{H} 7$ based on micro-gapped interdigitated electrode arrays. Biotechnol. Biotechnol. Equip. 2017, 1-9.

72. Wang, Y.; Alocilja, E. C., Gold nanoparticle-labeled biosensor for rapid and sensitive detection of bacterial pathogens. J. Biol. Eng. 2015, 9 (1), 16.

73. dos Santos, M. B.; Azevedo, S.; Agusil, J.; Prieto-Simón, B.; Sporer, C.; Torrents, E.; Juárez, A.; Teixeira, V.; Samitier, J., Label-free ITO-based immunosensor for the detection of very low concentrations of pathogenic bacteria. Bioelectrochemistry 2015, 101, 146152.

74. Jayamohan, H.; Gale, B. K.; Minson, B.; Lambert, C. J.; Gordon, N.; Sant, H. J., Highly sensitive bacteria quantification using immunomagnetic separation and electrochemical detection of guanine-labeled secondary beads. Sensors 2015, 15 (5), 12034-12052.

75. Setterington, E. B.; Alocilja, E. C., Rapid electrochemical detection of polyaniline-labeled Escherichia coli O157: H7. Biosens Bioelectron. 2011, 26 (5), 2208-2214.

76. Huang, H.; Liu, M.; Wang, X.; Zhang, W.; Yang, D.-P.; Cui, L.; Wang, X., Label-free 3D Ag nanoflower-based electrochemical immunosensor for the detection of Escherichia coli O157: H7 pathogens. Nanoscale Res. Lett. 2016, 11 (1), 507.

77. Li, Y.; Fang, L.; Cheng, P.; Deng, J.; Jiang, L.; Huang, H.; Zheng, J., An electrochemical immunosensor for sensitive detection of Escherichia coli O157: H7 using C 60 based biocompatible platform and enzyme functionalized Pt nanochains tracing tag. Biosens Bioelectron. 2013, 49, 485-491.

78. Tan, F.; Leung, P. H.; Liu, Z.-b.; Zhang, Y.; Xiao, L.; Ye, W.; Zhang, X.; Yi, L.; Yang, M., A PDMS microfluidic impedance immunosensor for E. coli O157: H7 and Staphylococcus aureus detection via antibody-immobilized nanoporous membrane. Sens. Actuator B 2011, 159 (1), 328-335.

79. Bekir, K.; Barhoumi, H.; Braiek, M.; Chrouda, A.; Zine, N.; Abid, N.; Maaref, A.; Bakhrouf, A.; Ouada, H. B.; Jaffrezic-Renault, N., Electrochemical impedance immunosensor for rapid detection of stressed pathogenic Staphylococcus aureus bacteria. Environ. Sci. Pollut. Res. 2015, 22 (20), 15796-15803.

80. Freitas, M.; Viswanathan, S.; Nouws, H.; Oliveira, M.; Delerue-Matos, C., Iron oxide/gold core/shell nanomagnetic probes and CdS biolabels for amplified electrochemical immunosensing of Salmonella typhimurium. Biosens Bioelectron. 2014, 51, 195-200.

81. Cheng, C.; Peng, Y.; Bai, J.; Zhang, X.; Liu, Y.; Fan, X.; Ning, B.; Gao, Z., Rapid detection of Listeria monocytogenes in milk by self-assembled electrochemical immunosensor. Sens. Actuator B 2014, 190, 900-906.

82. Chen, Q.; Wang, D.; Cai, G.; Xiong, Y.; Li, Y.; Wang, M.; Huo, H.; Lin, J., Fast and sensitive detection of foodborne pathogen using electrochemical impedance analysis, urease catalysis and microfluidics. Biosens Bioelectron. 2016, 86, 770-776.

83. Ahmed, A.; Rushworth, J. V.; Wright, J. D.; Millner, P. A., Novel impedimetric immunosensor for detection of pathogenic bacteria streptococcus pyogenes in human saliva. Anal. Chem. 2013, 85 (24), 12118-12125. 
84. Wan, Y.; Zhang, D.; Hou, B., Monitoring microbial populations of sulfate-reducing bacteria using an impedimetric immunosensor based on agglutination assay. Talanta 2009, 80 (1), 218-223.

85. Aronoff-Spencer, E.; Venkatesh, A. G.; Sun, A.; Brickner, H.; Looney, D.; Hall, D. A., Detection of Hepatitis $\mathrm{C}$ core antibody by dual-affinity yeast chimera and smartphonebased electrochemical sensing. Biosens Bioelectron. 2016, 86, 690-696.

86. Tuan, C. V.; Huy, T. Q.; Hieu, N. V.; Tuan, M. A.; Trung, T., Polyaniline nanowires-based electrochemical immunosensor for label free detection of Japanese encephalitis virus. Anal. Lett. 2013, 46 (8), 1229-1240.

87. Hayat, A.; Marty, J. L., Aptamer based electrochemical sensors for emerging environmental pollutants. Frontiers in Chemistry 2014, 2, 41.

88. Shahdordizadeh, M.; Taghdisi, S. M.; Ansari, N.; Langroodi, F. A.; Abnous, K.; Ramezani, M., Aptamer based biosensors for detection of Staphylococcus aureus. Sens. Actuator B 2017, 241, 619-635.

89. Andrew D. Ellington, A. D.; Szostak, J. W., In vitro selection of RNA molecules that bind specific ligands. Nature 1990, 346, 818-822.

90. Tuerk, C.; Gold, L., Systematic evolution of ligands by exponential enrichment: RNA ligands to bacteriophage T4 DNA polymerase. Science 1990, 249, 505-510.

91. So, H. M.; Park, D. W.; Jeon, E. K.; Kim, Y. H.; Kim, B. S.; Lee, C. K.; Choi, S. Y.; Kim, S. C.; Chang, H.; Lee, J. O., Detection and Titer Estimation of Escherichia coli Using Aptamer-Functionalized Single-Walled Carbon-Nanotube Field-Effect Transistors. Small 2008, 4 (2), 197-201.

92. Cella, L. N.; Sanchez, P.; Zhong, W.; Myung, N. V.; Chen, W.; Mulchandani, A., Nano aptasensor for protective antigen toxin of anthrax. Anal. Chem. 2010, 82 (5), 2042-2047.

93. Labib, M.; Zamay, A. S.; Kolovskaya, O. S.; Reshetneva, I. T.; Zamay, G. S.; Kibbee, R. J.; Sattar, S. A.; Zamay, T. N.; Berezovski, M. V., Aptamer-Based Viability Impedimetric Sensor for Bacteria. Anal. Chem. 2012, 84 (21), 8966-8969.

94. Düzgün, A.; Zelada-Guillén, G. A.; Crespo, G. A.; Macho, S.; Riu, J.; Rius, F. X., Nanostructured materials in potentiometry. Anal. Bioanal. Chem. 2011, 399 (1), 171-181.

95. Abbaspour, A.; Norouz-Sarvestani, F.; Noori, A.; Soltani, N., Aptamer-conjugated silver nanoparticles for electrochemical dual-aptamer-based sandwich detection of staphylococcus aureus. Biosens Bioelectron. 2015, 68, 149-155.

96. Bai, L.; Chen, Y.; Bai, Y.; Chen, Y.; Zhou, J.; Huang, A., Fullerene-doped polyaniline as new redox nanoprobe and catalyst in electrochemical aptasensor for ultrasensitive detection of Mycobacterium tuberculosis MPT64 antigen in human serum. Biomaterials 2017, 133, 11-19.

97. Thakur, H.; Kaur, N.; Sareen, D.; Prabhakar, N., Electrochemical determination of M. tuberculosis antigen based on Poly (3, 4-ethylenedioxythiophene) and functionalized carbon nanotubes hybrid platform. Talanta 2017, 171, 115-123.

98. Brosel-Oliu, S.; Ferreira, R.; Uria, N.; Abramova, N.; Gargallo, R.; Munoz-Pascual, F.-X.; Bratov, A., Novel impedimetric aptasensor for label-free detection of Escherichia coli O157:H7. Sens. Actuator B 2018, 255, 2988.

99. Guo, Y.; Wang, Y.; Liu, S.; Yu, J.; Wang, H.; Wang, Y.; Huang, J., Label-free and highly sensitive electrochemical detection of E. coli based on rolling circle amplifications coupled peroxidase-mimicking DNAzyme amplification. Biosens Bioelectron. 2016, 75, 315-319. 
100. Brosel-Oliu, S.; Ferreira, R.; Uria, N.; Abramova, N.; Gargallo, R.; Muñoz-Pascual, F.-X.; Bratov, A., Novel impedimetric aptasensor for label-free detection of Escherichia coli O157:H7. Sens. Actuator B 2018, 255, 2988-2995.

101. Burrs, S.; Bhargava, M.; Sidhu, R.; Kiernan-Lewis, J.; Gomes, C.; Claussen, J.; McLamore, E., A paper based graphene-nanocauliflower hybrid composite for point of care biosensing. Biosens Bioelectron. 2016, 85, 479-487.

102. Kaur, H.; Shorie, M.; Sharma, M.; Ganguli, A. K.; Sabherwal, P., Bridged Rebar Graphene functionalized aptasensor for pathogenic E. coli O78:K80:H11 detection. Biosens.

Bioelectron. 2017, 98, 486-493.

103. Reich, P.; Stoltenburg, R.; Strehlitz, B.; Frense, D.; Beckmann, D., Development of An Impedimetric Aptasensor for the Detection of Staphylococcus aureus. Int. J. Mol. Sci. 2017, 18 (11), 2484.

104. Jia, F.; Duan, N.; Wu, S.; Ma, X.; Xia, Y.; Wang, Z.; Wei, X., Impedimetric aptasensor for Staphylococcus aureus based on nanocomposite prepared from reduced graphene oxide and gold nanoparticles. Microchim. Acta 2014, 181 (9), 967-974.

105. Muniandy, S.; Dinshaw, I. J.; Teh, S. J.; Lai, C. W.; Ibrahim, F.; Thong, K. L.; Leo, B. F., Graphene-based label-free electrochemical aptasensor for rapid and sensitive detection of foodborne pathogen. Anal. Bioanal. Chem. 2017, 409, 6893-6905.

106. Dinshaw, I. J.; Muniandy, S.; Teh, S. J.; Ibrahim, F.; Leo, B. F.; Thong, K. L., Development of an aptasensor using reduced graphene oxide chitosan complex to detect Salmonella. J. Electroanal. Chem. 2017, 806, 88-96.

107. Ranjbar, S.; Shahrokhian, S.; Nurmohammadi, F., Nanoporous gold as a suitable substrate for preparation of a new sensitive electrochemical aptasensor for detection of Salmonella typhimurium. Sens. Actuator B 2018, 255, 1536-1544.

108. Sheikhzadeh, E.; M.Chamsaz b, A. P. F. T. a., E.W.H.Jager a, V.Beni, Label-free impedimetric biosensor for Salmonella Typhimurium detection based on poly[pyrrole-co3-carboxyl-pyrrole] copolymer supported aptamer. Biosens. Bioelectron. 2016, 80, 194200.

109. Luo, P.; Liu, Y.; Xia, Y.; Xu, H.; Xie, G., Aptamer biosensor fo rsensitive detection of toxin A of Clostridium difficile using gold nanoparticles synthesized by Bacillus stearothermophilus. Biosens. Bioelectron. 2014, 54, 217-221.

110. Zasloff, M., Antimicrobial peptides of multicellular organisms. Nature 2002, 415 (6870), 389.

111. Nguyen, L. T.; Haney, E. F.; Vogel, H. J., The expanding scope of antimicrobial peptide structures and their modes of action. Trends Biochem. Sci. 2011, 29 (9), 464-472.

112. Kulagina, N. V.; Lassman, M. E.; Ligler, F. S.; Taitt, C. R., Antimicrobial peptides for detection of bacteria in biosensor assays. Anal. Chem. 2005, 77 (19), 6504-6508.

113. Manoor, M. S.; Tao, H.; Clyton, J. D.; Sengupta, A.; Kaplan, D. L.; Naik, D. L.; Verma, R. R.; Omenetto, F. G.; McAlpine, M. C., Graphene-based wireless bacteria detection on tooth enamel. Nat. Commun. 2012, 3, 763.

114. Mannoor, M. S.; Zhang, S.; Link, A. J.; McAlpine, M. C., Electrical detection of pathogenic bacteria via immobilized antimicrobial peptides. Proc. Natl. Acad. Sci. U.S.A. 2010, 107 (45), 19207-19212.

115. Li, Y.; Afrasiabi, R.; Fathi, F.; Wang, N.; Xiang, C.; Love, R.; She, Z.; Kraatz, H.-B., Impedance based detection of pathogenic E. coli O157: H7 using a ferrocene-antimicrobial peptide modified biosensor. Biosens Bioelectron. 2014, 58, 193-199. 
116. Etayash, H.; Jiang, K.; Thundat, T.; Kaur, K., Impedimetric Detection of Pathogenic GramPositive Bacteria Using an Antimicrobial Peptide from Class IIa Bacteriocins. Anal. Chem. 2014, 86 (3), 1693-1700.

117. Lillehoj, P. B.; Kaplan, C. W.; He, J.; Shi, W.; Ho, C.-M., Rapid, electrical impedance detection of bacterial pathogens using immobilized antimicrobial peptides. J. Lab. Autom. 2014, 19 (1), 42-49.

118. Hoyos-Nogués, M.; Brosel-Oliu, S.; Abramova, N.; Muñoz, F.-X.; Bratov, A.; MasMoruno, C.; Gil, F.-J., Impedimetric antimicrobial peptide-based sensor for the early detection of periodontopathogenic bacteria. Biosens Bioelectron. 2016, 86, 377-385.

119. Neufeld, T.; Schwartz-Mittelmann, A.; Biran, D.; Ron, E.; Rishpon, J., Combined phage typing and amperometric detection of released enzymatic activity for the specific identification and quantification of bacteria. Anal. Chem. 2003, 75 (3), 580-585.

120. Zhou, Y.; Marar, A.; Kner, P.; Ramasamy, R. P., Charge-directed immobilization of bacteriophage on nanostructured electrode for whole-cell electrochemical biosensors. Anal. Chem. 2017, 89 (11), 5734-5741.

121. Ma, F.; Rehman, A.; Liu, H.; Zhang, J.; Zhu, S.; Zeng, X., Glycosylation of quinone-fused polythiophene for reagentless and label-free detection of E. coli. Anal. Chem. 2015, 87 (3), 1560-1568.

122. Yang, H.; Zhou, H.; Hao, H.; Gong, Q.; Nie, K., Detection of escherichia coli with a labelfree impedimetric biosensor based on lectin functionalized mixed self-assembled monolayer. Sens. Actuator B-Chem. 2016, 229, 297-304.

123. Dechtrirat, D.; Gajovic-Eichelmann, N.; Wojcik, F.; Hartmann, L.; Bier, F. F.; Scheller, F. W., Electrochemical displacement sensor based on ferrocene boronic acid tracer and immobilized glycan for saccharide binding proteins and E. coli. Biosens Bioelectron. 2014, $58,1-8$.

124. Gamella, M.; Campuzano, S.; Parrado, C.; Reviejo, A.; Pingarrón, J., Microorganisms recognition and quantification by lectin adsorptive affinity impedance. Talanta 2009, 78 (4-5), 1303-1309.

125. Neufeld, T.; Mittelman, A. S.; Buchner, V.; Rishpon, J., Electrochemical Phagemid Assay for the Specific Detection of Bacteria Using Escherichia c oli TG-1 and the M13KO7 Phagemid in a Model System. Anal. Chem. 2005, 77 (2), 652-657.

126. Shabani, A.; Zourob, M.; Allain, B.; Marquette, C. A.; Lawrence, M. F.; Mandeville, R., Bacteriophage-modified microarrays for the direct impedimetric detection of bacteria. Anal. Chem. 2008, 80 (24), 9475-9482.

127. Liébana, S.; Spricigo, D. A.; Cortés, M. P.; Barbé, J.; Llagostera, M.; Alegret, S.; Pividori, M. I., Phagomagnetic Separation and Electrochemical Magneto-Genosensing of Pathogenic Bacteria. Anal. Chem. 2013, 85 (6), 3079-3086.

128. Guo, X.; Kulkarni, A.; Doepke, A.; Halsall, H. B.; Iyer, S.; Heineman, W. R., Carbohydrate-based label-free detection of Escherichia coli ORN 178 using electrochemical impedance spectroscopy. Anal. Chem. 2011, 84 (1), 241-246.

129. Smartt, A. E.; Xu, T.; Jegier, P.; Carswell, J. J.; Blount, S. A.; Sayler, G. S.; Ripp, S., Pathogen detection using engineered bacteriophages. Anal. Bioanal. Chem. 2012, 402 (10), 3127-3146.

130. Richter, Ł.; Bielec, K.; Leśniewski, A.; Łoś, M.; Paczesny, J.; Hołyst, R., Dense Layer of Bacteriophages Ordered in Alternating Electric Field and Immobilized by Surface 
Chemical Modification as Sensing Element for Bacteria Detection. ACS Appl. Mater. Interfaces 2017, 9 (23), 19622-19629.

131. Han, J.-H.; Wang, M. S.; Das, J.; Sudheendra, L.; Vonasek, E.; Nitin, N.; Kennedy, I. M., Capture and Detection of T7 Bacteriophages on a Nanostructured Interface. ACS App. Mater. Interfaces 2014, 6 (7), 4758-4765.

132. Xi, F.; Gao, J.; Wang, J.; Wang, Z., Discrimination and detection of bacteria with a labelfree impedimetric biosensor based on self-assembled lectin monolayer. J. Electroanal. Chem. 2011, 656 (1-2), 252-257. 